\title{
Intra-annual stem growth dynamics of Lebanon Cedar along climatic gradients
}

\author{
Aylin Güney ${ }^{1} \cdot$ Manfred Küppers $^{1} \cdot$ Cyrille Rathgeber $^{2} \cdot$ Melahat Şahin $^{3}$. \\ Reiner Zimmermann ${ }^{1}$
}

Received: 22 July 2016/Accepted: 2 November 2016/Published online: 17 November 2016

(C) Springer-Verlag Berlin Heidelberg 2016

\begin{abstract}
Key message Onset of cambial activity in Lebanon Cedar is triggered by stem temperature but may be delayed by high site-LAI. Higher growth rates and treering widths were observed under better water and light availability. Daily stem radius variations were sensitive to humid conditions.

Abstract Studies on intra-annual dynamics of stem growth provide useful information on tree growth responses to environmental conditions, but are fragmentary for species from Mediterranean Mountain ranges. Lebanon Cedar is a frost and drought tolerant species, growing between 1000 and $2000 \mathrm{~m}$ a.s.1 in the Taurus Mountains (Turkey). Foresters see it as a potential candidate for plantation in Central European forests facing global warming. To describe the natural variability of Lebanon Cedar growth dynamics, five study sites were established: four along an altitudinal gradient at a natural site in SW-Turkey and one in a Lebanon Cedar plantation in Central Germany. Two stem growth monitoring methods were used: (1) bi-weekly microcoring during 2013 growing season and (2) point dendrometers during 2013 and 2014. Histological analyses were used to calibrate dendrometer records and to describe cambium phenology. Seasonal dynamics of xylem and
\end{abstract}

Communicated by E. Liang.

Aylin Güney

aylinguney13@gmail.com

1 Institute of Botany, University of Hohenheim, Stuttgart, Germany

2 LERFoB, INRA, AgroParisTech, 54000 Nancy, France

3 Department of Forest-Village Relations, Antalya Regional Directorate of Forestry, Antalya, Turkey stem radial increments were modelled by Gompertz functions. Onset of cambial activity was observed 1-2 weeks after stem temperatures reached a threshold of $5{ }^{\circ} \mathrm{C}$ but could be delayed by high site-LAI. Cedars growing under better light and water availability showed higher growth rates and wider tree rings. Daily stem radius variations (dSRV) extracted from dendrometer records were negatively related to vapor pressure deficit and global radiation; multiple linear regressions explained $30-52 \%$ of dSRV variance being dominated by relative humidity, precipitation, and soil water content. Best growth performance was observed at the German site, likely for a continuous water supply throughout the year, underlining the potential of Lebanon Cedar for Central European Forestry.

Keywords Lebanon Cedar - Point dendrometer .

Microcoring $\cdot$ Cambial activity $\cdot$ Tree-ring formation .

Microclimate
Abbreviations
A Final annual tree-ring width
$\mathrm{bE} \quad$ Onset of the enlarging phase
bL Onset of the cell-wall lignification phase
bM Onset of the mature phase
CA Cambial activity
$\mathrm{cE}$ Cessation of the enlarging phase
cL Cessation of the cell-wall lignification phase
CRF Cedar Research Forest
$d \quad$ Time required for major period of tree-ring
formation
$\mathrm{dE} \quad$ Duration of the enlarging phase
dL Duration of the lignification phase
DOY Day of year
dSRV Daily stem radius variation
dX Duration of xylogenesis 


$\begin{array}{ll}\text { EBG } & \text { Ecological Botanical Gardens } \\ \text { gR } & \text { Global radiation } \\ \text { LAI } & \text { Leaf area index } \\ \text { MAT } & \text { Mean annual air temperature } \\ \text { Pp } & \text { Precipitation } \\ r & \text { Mean tree-ring formation rate (during growth } \\ & \text { period) } \\ \text { rH } & \text { Relative air humidity } \\ \text { RSI } & \text { Radial stem increase } \\ \text { ST } & \text { Stem temperature } \\ \text { SWC } & \text { Soil water content } \\ \text { Ta } & \text { Air temperature }\left(\mathrm{Ta}_{\text {mean }}: \text { daily mean, } \mathrm{Ta}_{\text {max }}: \text { daily }\right. \\ & \text { maximum, and Tamin: daily minimum) } \\ \text { TAP } & \text { Total annual precipitation } \\ t_{\mathrm{p}} & \text { Time of inflection point } \\ \text { Ts } & \text { Soil temperature } \\ \text { VPD } & \text { Vapor pressure deficit }\end{array}$

\section{Introduction}

Studies on intra-annual dynamics of stem growth are of high interest, because they allow for an insight on processes underlying tree-ring formation and on factors affecting those processes (Bouriaud et al. 2005; Rathgeber et al. 2011a). Global warming is expected to increase temperatures and the intensity and frequency of summer droughts (Stocker 2014), which will affect dynamics of tree growth and may lead to a decrease in forest productivity (Ciais et al. 2005; Deslauriers et al. 2007). Observing changes in stem radius, cambial activity (CA), and wood formation at high resolution in combination with daily variations of climatic conditions can improve our understanding of how tree growth responds to climate change (Michelot et al. 2012; Rossi et al. 2006b). For this, several methods are available among which dendrometer measurements and repeated microcoring are the most well known. Dendrometers allow for quasi-continuous measurements of variations in stem radius (including bark growth, phloem and xylem formation) over long time periods (Herzog et al. 1995) without creating significant disturbances in cambial and woody tissues nearby. Furthermore, they allow for monitoring of trees reactions to short-term changes in microclimatic conditions. However, when interpreting results one has to take into account water-related swelling and shrinkage of the stem, especially of the bark, which interfere with the stem growth signal (Deslauriers et al. 2007; Downes et al. 1999; Mäkinen et al. 2003; Zweifel and Häsler 2001). Microcoring allows for detailed investigation of tree-ring formation directly at the cellular level by repeatedly extracting small wood samples. With this method, it is possible to accurately describe phenology of CA and intraannual dynamics of wood formation (Mäkinen et al. 2008; Rathgeber et al. 2011b; Rossi et al. 2006a), and to describe the kinetics of xylem cell differentiation: radial cell enlargement, secondary wall thickening and lignification, and cell death (Cuny et al. 2014). However, wood samples have to be extracted regularly in defined time intervals, which require repeated wounding of the tree, regular visit of the monitored site, and tedious sample preparation and observation in the laboratory. Combining both methods may lead to more powerful results by minimizing their respective weaknesses. Wood formation monitoring (e.g., microcoring) may help to better understand dendrometer records, which are more widely spread in the scientific community but much less understood. On the other hand, dendrometers may allow exploring tree physiological reactions at higher time resolution (hourly or daily).

For the Mediterranean region, there are several studies investigating intra-annual growth of tree rings either by wood formation monitoring (Camarero et al. 1998; de Luis et al. 2011; del Castillo et al. 2016) or by dendrometers (Vieira et al. 2013). They show that wood formation is siteand species specific and demonstrate the importance of climatic conditions on onset and cessation of growth and of growth performance. So is the cambial onset mainly triggered by temperature in most biomes (Rossi et al. 2007), while, for example, growth cessation may be influenced by water availability in drier regions, such as the Mediterranean or may be limited by photoperiod, e.g., in temperate and boreal regions (Rossi et al. 2006c; Vieira et al. 2014). In co-occurring species, conifers generally show an earlier onset of stem growth than broadleaf species (e.g., Zhai et al. 2012). Studies that combine dendrometer and microcoring are scarce, but they underline the interrelation between wood anatomy and stem radial variation and allow a more precise prediction of tree growth based on climatic conditions (Camarero et al. 2010; Cocozza et al. 2016; Linares et al. 2009; Vieira et al. 2014).

To our knowledge, studies on the intra-annual growth dynamics of the montane Mediterranean Lebanon Cedar (Cedrus libani A. Rich) are still very rare. Today, Lebanon Cedar is mainly distributed as pure natural stands along the Taurus Mountain Range of Southern Turkey (800-2200 m a.s.l, Akkemik 2003), which offers biologically and ecologically valuable ecosystems to a large number of endemic species (Kavgac1 et al. 2010). Because of its adaptability to temperature extremes and summer drought and its valuable timber, it is one of the major commercial tree species in Turkey (Brooks et al. 2008) used in many forestation and afforestation projects within (Boydak 2007) and outside Turkey (e.g., Italy, Ducci et al. 2007). Its potential for Central European forestry was recently 
reviewed, underlining its promising potential for establishing stable and productive forest stands under a changing climate (c.f. Messinger et al. 2015). It is then of interest to learn more about its intra-annual growth dynamics under different site and climatic conditions. We used microcoring and point dendrometers in combination with local weather stations to analyze the dynamics of wood formation of Lebanon Cedar under different climates (sub-continental in Germany and Mediterranean in Turkey) and along a large range of altitudes during the growth periods of 2013 and 2014. To describe natural variability, four measurement sites were established in a Lebanon Cedar forest in SWTurkey (1000-2000 m a.s.l) and one within a cedar plantation in Bayreuth, Central Germany (360 m a.s.l), which represents a potential area for establishing future Lebanon Cedar stands.

The objectives of this study are to describe (1) wood formation phenology; (2) intra-annual radial growth dynamics; (3) comparing results from microcoring and dendrometer records; to (4) better understand which climatic factors drive Lebanon Cedar radial growth. Finally, the growth potential of Lebanon Cedar with respect to climate change will be discussed.

\section{Materials and methods}

\section{Study sites and tree selection}

The study was conducted during 2013 and 2014 on individuals of Lebanon Cedar at five sites of different environmental characteristics and along an elevational gradient (Table 1). Four of these sites (T1-T4) were located at the Cedar Research Forest (CRF), which is within the district of Elmali and situated $130 \mathrm{~km}$ southwest of Antalya, Turkey (Fig. 1). The CRF mainly consists of pure natural Lebanon Cedar stands and is characterized by an oroMediterranean climate with a drought period during summer (from June to September) and cold winters (Fig. 2). Mean annual value (1968-2000, $1665 \mathrm{~m}$ a.s.l) of air temperature (MAT) is $7.4^{\circ} \mathrm{C}$ with absolute air temperature extremes of -31 and $+34{ }^{\circ} \mathrm{C}$. Mean total annual precipitation (TAP) is $725 \mathrm{~mm}$ with rainfall mainly occurring during winter months (Basaran et al. 2008; Senitza 1989). The fifth study site (O1) was located within a Lebanon Cedar plantation at the Ecological Botanical Gardens (EBG) at Bayreuth, Germany. Seed material of these cedar individuals originated from the same province, where the CRF is located and was germinated and cultivated in Germany in 1978. The 2-year-old seedlings were planted in the EBG in 1980 (Messinger et al. 2015). The EBG is characterized by a transition from oceanic to continental (so-called "sub-continental") climate with mild-to-cold winters and warm summers without any drought period during the year (Fig. 2). MAT is $8.2^{\circ} \mathrm{C}$ (1971-2000, $360 \mathrm{~m}$ a.s.l), and measured absolute air temperature extremes are -24 and $+36{ }^{\circ} \mathrm{C}$. Mean TAP is $724 \mathrm{~mm}$ (Foken 2007). To determine Leaf Area Index (LAI) of the sites, hemispherical photographs of the forest canopy were taken from the ground and analyzed using HemiView image analysis software (1999 Delta-T Devices Ltd, Cambridge, UK). To measure seasonal dynamics of stem growth in Lebanon Cedar, nine individuals were randomly selected within a circular plot (radius $=20 \mathrm{~m}$ ) at each Turkish site (Table 2). None of the selected trees had visible damage. Age at breast height $(1.3 \mathrm{~m})$ was estimated by extracting tree cores using an increment borer (Suunto $300 / 400 \mathrm{~mm}$, Finland). At the EBG, five cedar individuals (Table 2) were selected from a tree row planted parallel along a paved road in 1988 (Messinger et al. 2015).

\section{Microclimate measurements}

Meteorological stations (WatchDog 2700 Weather Station, Spectrum Technologies Inc., Plainfield, IL, USA) were installed at $\mathrm{T} 1$ and $\mathrm{T} 3$ in open areas (Fig. 1) to measure air $\left(\mathrm{Ta},{ }^{\circ} \mathrm{C}\right)$ and soil temperature $\left(\mathrm{Ts},{ }^{\circ} \mathrm{C}\right)$, precipitation $(\mathrm{Pp}$, $\mathrm{mm}$ ), soil water content (SWC, \%), relative air humidity $(\mathrm{rH}, \%)$, and global radiation $\left(\mathrm{gR}, \mathrm{W} / \mathrm{m}^{2}\right)$. At sites $\mathrm{T} 2$ and $\mathrm{T} 4$, Ta and $\mathrm{rH}$ were measured using $\mathrm{HOBO}^{\circledR}$ Pro series loggers (Onset Computer Corporation, MA, USA) mounted on a tree within the plot approximately $2 \mathrm{~m}$ above ground. Ts were measured with thermocouples, and SWC was measured with a Theta Equitensiometer ML-2 (EQ ML2 9-23, Delta-T devices, England) at $\mathrm{T} 2$ and a Stevens ${ }^{\circledR}$ Hydra Probe (Stevens Water Monitoring Systems, Inc., Portland, USA) at T4 and recorded using data loggers (DL2e Data logger, Delta-T devices Ltd., Cambridge). Climate data for $\mathrm{O} 1$ were derived from the meteorological station at the EBG (360 m a.s.l., BayCEER). Ts and SWC were measured at a depth of approximately $0.15 \mathrm{~m}$. Stem temperature (ST) was measured using thermocouples and recorded by data loggers (DL2e). These thermocouples were installed at breast height within the outer stem (N facing) under the bark of three cedar individuals to get a representative mean ST per site. Climate variables were measured at 10-30 min time steps and were later aggregated to daily values (daily mean: $\mathrm{Ta}_{\text {mean }}$, maximum: $\mathrm{Ta}_{\max }$, minimum: $\mathrm{Ta}_{\min }$, and sum: Pp). $\mathrm{gR}$ was converted from hourly means into daily sums and expressed as $\mathrm{MJ} \mathrm{m}{ }^{-2}$ day $^{-1}$. In addition, daily means of vapor pressure deficit (VPD, hPa) were calculated from site-specific $\mathrm{Ta}_{\text {mean }}, \mathrm{rH}$, and air pressure values for all sites.

A temperature threshold was determined after which CA was likely to start within a defined time span (e.g., 1 week). Therefore, daily means of temperature variables were 
Table 1 Location and characteristics of the study sites

\begin{tabular}{|c|c|c|c|c|c|}
\hline Site & $\mathrm{O} 1$ & $\mathrm{~T} 4$ & $\mathrm{~T} 3$ & $\mathrm{~T} 2$ & $\mathrm{~T} 1$ \\
\hline Location & EBG Bayreuth $^{\mathrm{a}}$ & CRF Elmali ${ }^{\mathrm{b}}$ & CRF Elmali ${ }^{\mathrm{b}}$ & CRF Elmali ${ }^{\mathrm{b}}$ & CRF Elmali ${ }^{\mathrm{b}}$ \\
\hline Latitude & $49.925915^{\circ} \mathrm{N}$ & $36.57800^{\circ} \mathrm{N}$ & $36.57771^{\circ} \mathrm{N}$ & $36.58520^{\circ} \mathrm{N}$ & $36.58422^{\circ} \mathrm{N}$ \\
\hline Longitude & $11.582851^{\circ} \mathrm{E}$ & $29.96881^{\circ} \mathrm{E}$ & $29.98542^{\circ} \mathrm{E}$ & $30.02035^{\circ} \mathrm{E}$ & $30.03077^{\circ} \mathrm{E}$ \\
\hline Altitude (m a.s.1.) & 360 & 1055 & 1355 & 1665 & 1960 \\
\hline Total plot area (ha) & Single tree row & 0.126 & 0.126 & 0.126 & 0.126 \\
\hline Forest type & Plantation & Natural forest & Natural forest & Natural forest & Natural forest (tree line) \\
\hline Exposure & NS-orientation & NW & NW & NW & NW \\
\hline Stand inclination & Level terrain & $20^{\circ}$ & $26^{\circ}$ & $40^{\circ}$ & $16^{\circ}$ \\
\hline Soil & Clay and sandy loam & Clayey loam to clay & Clay to clayey loam & Clay loam to clay & Clay loam \\
\hline $\mathrm{pH}\left(\mathrm{H}_{2} \mathrm{O}\right)$ & $4.4-5.3$ & $7.20-8.15$ & $7.23-7.56$ & $7.63-8.03$ & $7.61-7.79$ \\
\hline Stand density $\left(\text { trees } \mathrm{ha}^{-1}\right)^{\mathrm{c}}$ & - & 334 & 533 & 501 & 478 \\
\hline Basal area $\left(\mathrm{m}^{2} \mathrm{ha}^{-1}\right)$ & - & 30.0 & 74.4 & 46.1 & 50.4 \\
\hline $\operatorname{LAI}^{\mathrm{d}}\left(\mathrm{m}^{2} \mathrm{~m}^{-2}\right)$ & - & $2.3 \pm 0.65$ & $3.2 \pm 0.89$ & $2.9 \pm 0.46$ & $1.04 \pm 0.45$ \\
\hline
\end{tabular}

Soil properties and $\mathrm{pH}\left(\mathrm{H}_{2} \mathrm{O}\right)$ values according to Basaran et al. (2008)

${ }^{a}$ Bayreuth, Germany (D)

b Elmali, Turkey (TR)

c Only trees with a DBH $>10 \mathrm{~cm}$

${ }^{\mathrm{d}}$ LAI values were calculated via the HemiView image analysis program (Delta-T Devices, Cambridge, UK) for the Turkish sites

compared in $0.1^{\circ}$ steps between all sites within a time frame of 2 months before onset of CA. For dSRV-climate analysis, missing $\mathrm{Pp}$ and $\mathrm{gR}$ data at $\mathrm{T} 2$ and $\mathrm{T} 4$ were extrapolated using WorldClim and HemiView (Delta-T Devices Ltd.) data, respectively. An overview about all measured climate variables is given in Table 3 .

\section{Growth monitoring using point dendrometers}

In 2013 and 2014, stem growth was monitored hourly on the nine Lebanon Cedar individuals selected at T1-T4 and the five individuals selected at O1 (Table 2) using point dendrometers (linear displacement potentiometers, accuracy $<10 \mu \mathrm{m}$; MMR 10_11 R5 K, MEGATRON Elektronik AG \& Co., Munich, Germany). Those were mounted at breast height on stainless steel frames and fixed to the slope-parallel sides of the stem. Steel frames were attached to the stem by two screws which were placed at least $5 \mathrm{~cm}$ apart from the measuring point and at least $5 \mathrm{~cm}$ deep into the xylem (Herzog et al. 1995). The contact head of the dendrometer was placed at the cortex surface after removing the bark without damaging living tissue (Zweifel et al. 2006). Dendrometers were wrapped up in aluminum foil and covered with styrofoam to protect them from direct solar radiation and precipitation. Radial stem changes were recorded using data loggers (DL2e). To extract stem growth signals from dendrometer records, we used the 'daily mean approach' (Deslauriers et al. 2007). Hourly dendrometer records were averaged on a daily basis, and daily stem radius variation (dSRV) was calculated as the difference between the mean value of two consecutive days (Deslauriers et al. 2007; Tardif et al. 2001). Only the main period of radial stem increase (RSI) was considered for dSRV analysis to exclude measurement variability that is higher than radial growth at the beginning and end of growth period (cf. Deslauriers et al. 2007). This period is defined by a sharp, almost linear increase of the dendrometer records. When initiation of this linear increase was observed, dendrometer records were set to zero. The end of the period of the main RSI was defined as the date when $90 \%$ of the annual radial increment $\left(A_{90 \%}\right)$ was reached $(A=$ upper asymptote, see section "Modeling growth dynamics").

\section{Wood formation monitoring with microcores}

To investigate tree-ring growth at cellular level (microscopically), microcores were extracted bi-weekly during the growing season of 2013 (March to October) from stems of three Lebanon Cedar trees per site (Güney et al. 2015). All individuals chosen for microcoring were also selected for dendrometer measurements (Table 2). Microcores were extracted using a Trephor $\odot$ (Rossi et al. 2006a) at breast height from the slope-parallel side of the stem and on the stem-side opposite to the dendrometer. Before sampling, the outer bark was carefully removed. To avoid tissue damage and wound reactions, microcores were taken along the stem in a spiral pattern with at least $5 \mathrm{~cm}$ distance 
Fig. 1 Location of the four study sites (T1-T4, white dots) at the Elmali Cedar Research Forest in Antalya, Turkey. Black triangles represent the location of weather stations (at $\mathrm{T} 1$ and $\mathrm{T} 3$ )
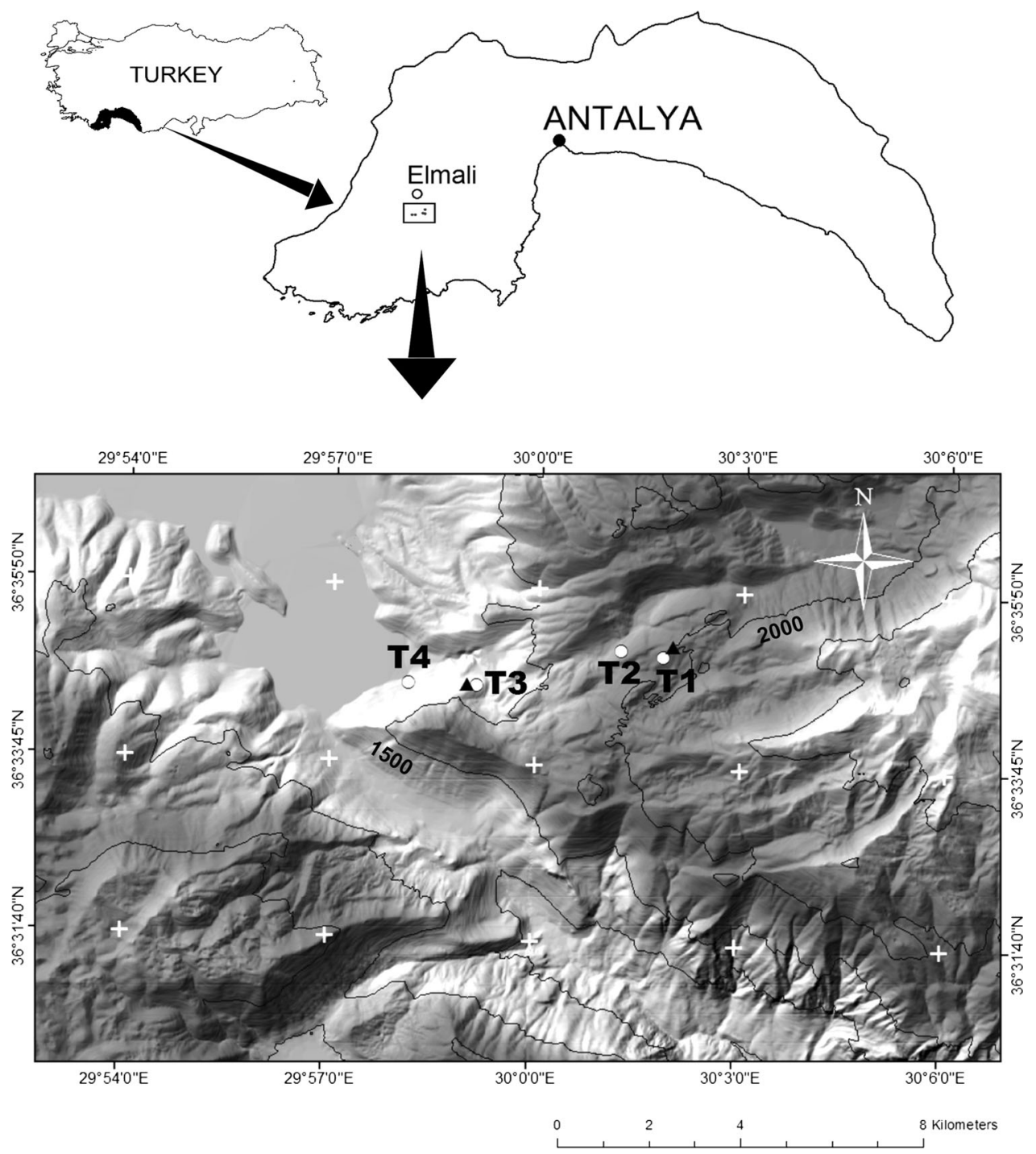

between extraction points (Deslauriers et al. 2003a). Samples were stored in a fixative solution and prepared in the laboratory for histological analysis, as described in Güney et al. (2015). Transverse sections of the microcores were examined and photographed under a Zeiss Axioplan microscope. For each sample, the number of cells in the developing tree ring (cells in the cambial zone, enlargement, cell-wall lignification, and mature tracheids) and the current radial width of the tree ring were determined along three radial files per transverse section and then averaged for further data analyses (Deslauriers et al. 2003a; Rossi et al. 2007). For results on cell counts, see Güney et al. (2015). We determined the beginning of CA as a distinct increase in the number of cambial cells (number of cambium cells $>$ number of dormant cambium cells) which are considered to be xylem cells in the postcambial growth stage (Gricar et al. 2006).
Critical dates and durations of wood formation were computed from raw cell count data using the R Package CaviaR, based on logistic regressions (Rathgeber et al. 2011b). The onset of enlarging (bE), cell-wall lignification (bL) and mature phases (bM) and cessation of enlarging (cE) and cell-wall lignification phases (cL) were defined as those dates at which $50 \%$ of the radial files were active or non-active. From these critical dates, durations of enlarging (dE) and lignification phases $(\mathrm{dL})$ as well as duration of xylogenesis $(\mathrm{dX})$ could be computed. Because the assumption of normality was not met by all parameters of critical dates and durations, a non-parametric Kruskal-Wallis test was performed to detect if there are significant differences between study sites. If significant differences were present, analyses were followed by Mann-Whitney $U$ tests. 
T1 (EImali, TR) $1960 \mathrm{~m}$
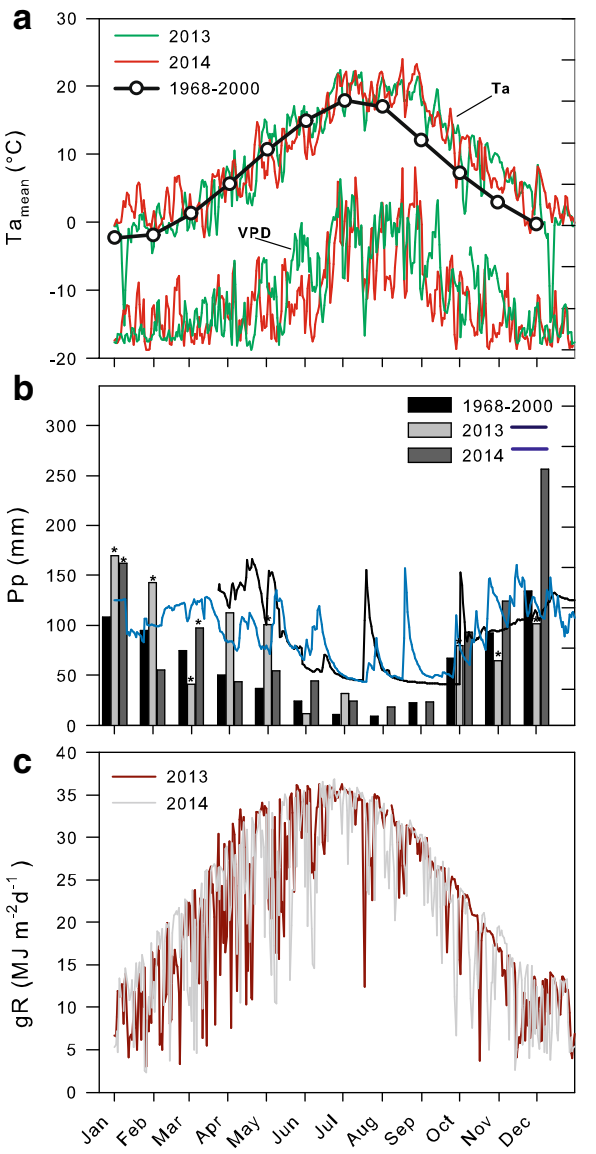

T3 (Elmali, TR) 1355 m
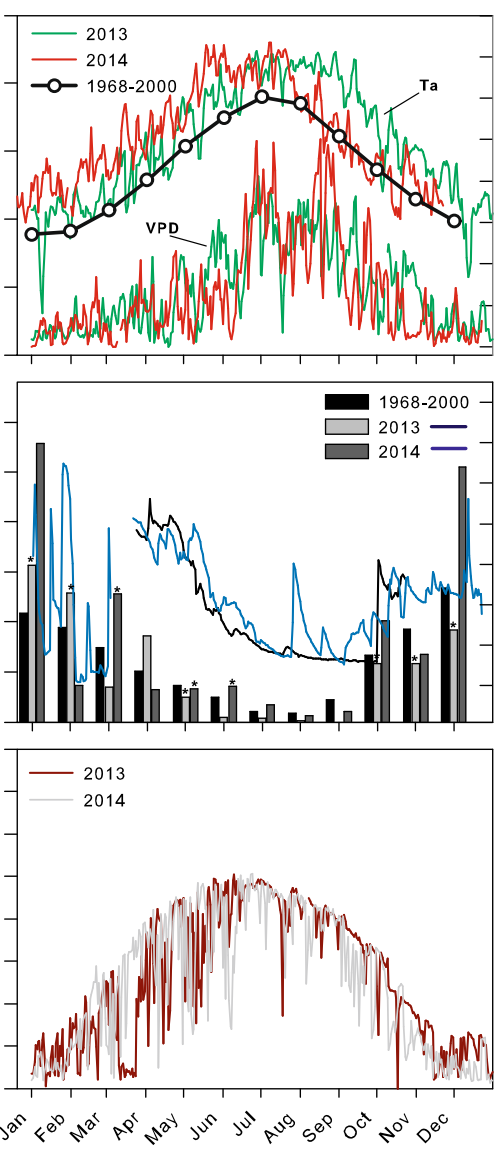

01 (Bayreuth, D) $360 \mathrm{~m}$

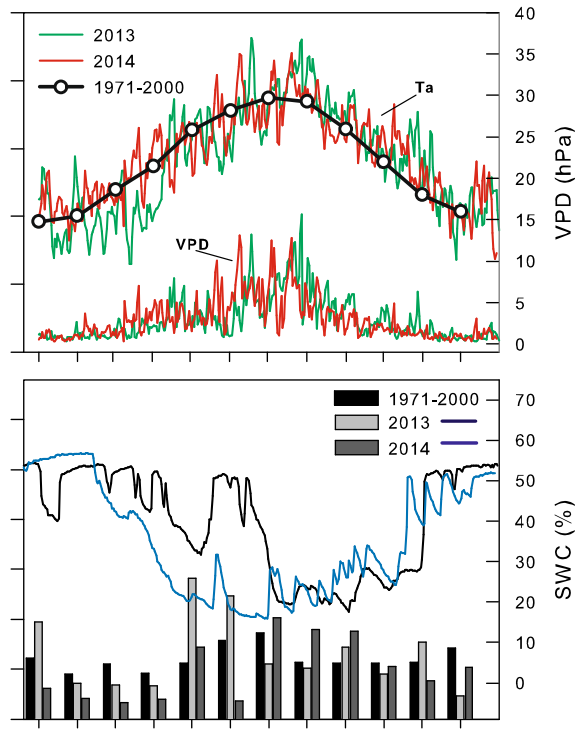

Month

Fig. 2 Climate variables recorded during the growing seasons of 2013 and 2014 at the Turkish sites T1 (left column) and T3 (middle column) and the German site O1 (right column) with a daily means of air temperature $\left(\mathrm{Ta}_{\text {mean }}\right.$; lines with circles represent the long-term average) and vapor pressure deficit (VPD; green lines 2013, red lines 2014), b daily means of soil water content (SWC; blue lines 2013, dark blue lines 2014), monthly sums of precipitation (Pp; black bars long-term average, grey bars 2013, dark grey bars 2014), and $\mathbf{c}$ daily totals of global radiation (gR; dark red lines 2013, grey lines 2014). For each respective parameter, scales of the $y$-axis are identical. Bars indicated with a star (in b) represent extrapolated Pp data, where sitespecific data were incomplete or missing
Table 2 Characteristics of the studied Lebanon Cedar trees

\begin{tabular}{llllll}
\hline Site & O1 & T4 & T3 & T2 & T1 \\
\hline Number of trees $(n)$ & 4 & 9 & 7 & 7 & 7 \\
DBH $(m)$ & $0.35 \pm 0.04$ & $0.34 \pm 0.13$ & $0.31 \pm 0.15$ & $0.33 \pm 0.09$ & $0.26 \pm 0.13(1.68)^{\mathrm{b}}$ \\
Age (year) & 35.0 & $75.0 \pm 33.6$ & $89.4 \pm 32.9$ & $88.9 \pm 16.6$ & $47 \pm 12.9(300)^{\mathrm{b}}$ \\
Height $(\mathrm{m})$ & $13.5 \pm 1.6$ & $14.8 \pm 3.9$ & $18.0 \pm 6.5$ & $20.2 \pm 1.2$ & $8.8 \pm 2.1$ \\
\hline
\end{tabular}

Trees which were not used in the analysis (because of sensor damage or loss of data) are not included Values present mean $\pm \mathrm{SD}$

a Age at $\mathrm{DBH}$

b At T1, one of the study trees was very old; therefore, age and DBH of this tree are listed separately in parentheses

\section{Modeling growth dynamics}

Stem radial growth during a growing season can be accurately described by the Gompertz model, which can fit adequately tree-ring increment (from dendrometers) and cell number increase (from microcoring) through time (Deslauriers et al. 2003b; Rossi et al. 2006c):

$y=A \exp [-\exp (b-k t)]$

where $y$ is the cumulative sum of growth, $A$ is the upper asymptote of the total number of xylem cells (or total 
Table 3 Overview of the measured climate variables and measurement devices at the five Lebanon Cedar study sites

\begin{tabular}{lllllll}
\hline Climate variables (unit) & Abbrev. & T1 & T2 & T3 & T4 & O1 \\
\hline Air temperature $\left({ }^{\circ} \mathrm{C}\right)$ & Ta & WD & H & WD & H & WS \\
Stem temperature $\left({ }^{\circ} \mathrm{C}\right)$ & ST & Th & Th & Th & Th & Th \\
Soil temperature $\left({ }^{\circ} \mathrm{C}\right)$ & Ts & Th & Th & Th & Th & WS \\
Precipitation $(\mathrm{mm})$ & Pp & WD & ex WC & WD & ex WC & WS \\
Relative air humidity $(\%)$ & rH & WD & H & WD & H & WS \\
Soil water content $(\%)$ & SWC & WD & TE & WD & HSP & WS \\
Global radiation $\left(\mathrm{MJ} \mathrm{m}^{-2}\right.$ day $\left.^{-1}\right)$ & gR & WD & ex HV & WD & ex HV & WS \\
\hline
\end{tabular}

$W D$ WatchDog weather station, $H$ HOBO logger, $T h$ measured using thermocouples, WS Weather station at the EBG, ex data extrapolated via WorldClim (WC) or HemiView (HV), TE Theta Equitensiometer ML-2, HSP Stevens ${ }^{\circledR}$ Hydra Probe annual tree-ring growth), $b$ is the $x$-axis placement parameter, $k$ is the rate of change parameter, and $t$ is the time as day of year (DOY) (Cheng and Gordon 2000). Growth rate of tree-ring formation can be described by the first derivative of the Gompertz function. The inflection point $\left(t_{\mathrm{p}}\right)$ corresponds to the maximum value of growth rate and can be calculated as $t_{\mathrm{p}}=b / k$ (Rossi et al. 2006c). The weighted mean absolute cell formation rate $(r)$ and the time required for the major period of tree-ring formation $(d)$ can be described as

$r=\frac{A k}{2(v+2)}$

$d=\frac{2(v+2)}{k}$

where $v=0.0001$, since the Gompertz function is a special case of the Richards function (Deslauriers et al. 2003b). Variables obtained from Gompertz fittings $\left(A, t_{\mathrm{p}}\right.$, and growth rate at $t_{\mathrm{p}}, r$, and $d$ ) of dendrometer data were compared among study sites using ANOVA. Tests of normal distribution and homogeneity of variances were performed using Kolmogorov-Smirnov and Levene tests $(p>0.05)$. All variables showed the required normal distributions. Differences between sites were assessed using either Tukey or Games-Howell post hoc tests for those cases that did or did not met the requirements for homogeneity of variances, respectively. Differences between years were compared using $t$ tests (confidence interval: $95 \%)$.

\section{Statistical analyses}

To assess climatic sensitivity of dSRV, Pearson correlation coefficients were calculated between dSRV and climate variables $\left(\mathrm{Ta}_{\text {mean }}, \mathrm{Ta}_{\max }\right.$, and $\mathrm{Ta}_{\text {min }}$; mean $\mathrm{Ts}$, mean $\mathrm{ST}, \mathrm{Pp}$ sum, mean SWC, mean $\mathrm{rH}$, gR sum, and mean VPD). To assess the overall amount of variability in dSRV explained by climate variables and DOY, we used multiple stepwise regression analysis. To reduce collinearity among variables, collinearity diagnosis was performed. To avoid phases of measurement variability higher than radial growth, only main periods of growth were considered for calculations (Deslauriers et al. 2007). Analyses were performed on both years together via SPSS v20.0 (SPSS Inc., Chicago, IL, USA) with a significance level of 0.05 .

\section{Results}

\section{Climate in 2013 and 2014}

In 2013, MAT exceeded the long-term mean $\left(7.4^{\circ} \mathrm{C}\right)$ at all Turkish sites (T1: $8.8{ }^{\circ} \mathrm{C}$, T2: $9.2{ }^{\circ} \mathrm{C}$, T3: $11.1{ }^{\circ} \mathrm{C}$, and T4: $\left.12.6^{\circ} \mathrm{C}\right)$. At $\mathrm{O} 1$, it was identical to the long-term mean $\left(8.2^{\circ} \mathrm{C}\right)$. In 2014 , MAT exceeded the long-term means and the values of 2013 at all sites $\left(\mathrm{T} 1: 9.3{ }^{\circ} \mathrm{C}, \mathrm{T} 2: 9.4{ }^{\circ} \mathrm{C}, \mathrm{T} 3\right.$ : $11.5^{\circ} \mathrm{C}$, T4: $13.0^{\circ} \mathrm{C}$, and $\mathrm{O} 1: 8.9^{\circ} \mathrm{C}$ ) indicating a general rise in temperature between 2 years. Maximum VPD values were observed between June and September, reaching up to $20 \mathrm{hPa}$ at the Turkish sites and $15 \mathrm{hPa}$ at the German site (Fig. 2). SWC was lowest at T1 and highest at $\mathrm{O} 1$ in both years, while minimum values were reached around September and July, respectively. At the Turkish sites, measured TAP was in both years above the long-term mean (725 mm). TAP was lower in 2013 than in 2014 and tended to be higher at T1 (2013: $754 \mathrm{~mm}$ and 2014: $1112 \mathrm{~mm}$ ) than at T3 (2013: $698 \mathrm{~mm}$ and 2014: $1010 \mathrm{~mm}$ ). Both years exhibited a distinct drought period during summer with the lowest precipitation values reached in August and September 2013 (T1: $0 \mathrm{~mm}$, T3: $1.4 \mathrm{~mm}$ ). At the German site, TAP in 2013 amounted to $789.7 \mathrm{~mm}$, which was above the long-term mean of $724 \mathrm{~mm}$, while in 2014, it amounted to $600 \mathrm{~mm}$ being clearly lower than the longterm mean. Precipitation was evenly distributed over the years, but exceptionally low during June 2014 (18.1 mm).

\section{Wood formation phenology}

Cambium and wood formation phenologies were observed by repeated microcoring during the growing season of 
2013. The onset of CA, as characterized by a distinct increase of the number of cambial cells above the cell number of the dormant cambium, could be observed at all study sites (Fig. 3c; Table 4). When daily mean ST continuously remained above a threshold of $5{ }^{\circ} \mathrm{C}$, cambia became active approximately 1-2 weeks later, so, likely, this temperature acts as a signal to the respective cambium. Only at T3, the cambium needed 4 weeks to become active (Fig. 3b-c). Critical dates (DOY) and durations (Table 4) of wood formation phenology showed significant differences $(p<0.05)$ between the five study sites (Table 5), except for bM which started approximately around 11 June (Kruskal-Wallis test, $\chi^{2}=8.63, \quad p=0.071$ ). Cell enlargement (bE) started first at T4 around 13 April (DOY 102) and last around 4 weeks later at T1 (DOY 130) showing a trend of later wood formation onsets with increasing altitude (Fig. 4a). Beginning of cell-wall lignificaiton (bL) followed bE after 16 days at the earliest (Fig. 4b). Cell enlargement ended first at T3 and last at $\mathrm{O} 1$ lasting approximately between 3 and 7 months, respectively (Fig. 4d, f). Cessation of lignification (cL) followed
cE approximately 4-6 weeks later. Only at $\mathrm{O} 1$ dates for $\mathrm{cE}$ and cL were identical (Fig. 4e). All in all, cessation of wood formation showed no clear altitudinal trend. While $\mathrm{dL}$ lasted around 2-4 weeks longer than $\mathrm{dE}$ at the Turkish sites, it appeared to last shorter at O1 (Fig. 4f-g). Overall, xylogenesis of Lebanon Cedar growing at different altitudes lasted between 5 and 7 months, with the shortest durations at T3 (about 129 days) and the longest at T4 and O1 (173 and 192 days, respectively) (Fig. 4h), showing an altitudinal trend.

\section{Radial growth dynamics and inter-annual variability}

\section{Radial growth dynamics}

At all sites, dendrometer records were characterized by a 'plateau' (Wang et al. 2015) during winter dormancy and early spring and a progressive almost linear RSI during the growing season with typical diurnal stem radius fluctuations of swelling and shrinking (Fig. 3). The beginning of
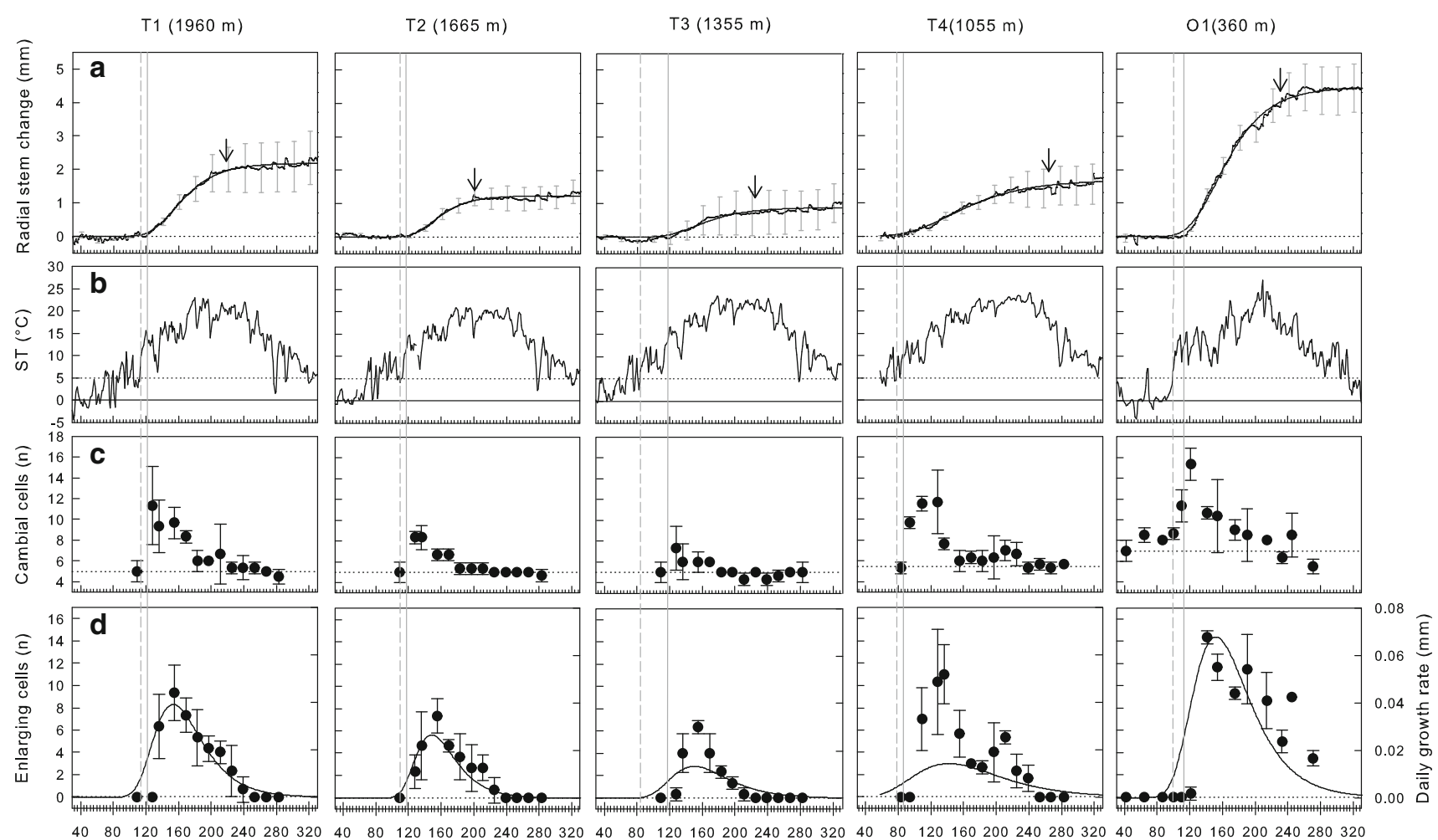

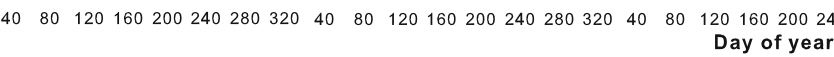

Fig. 3 a Mean radial stem change of Lebanon Cedar at the Turkish sites (T1 to T3: $n=7 ; \mathrm{T} 4: n=9)$ and the German site $(\mathrm{O} 1: n=4)$ in 2013 and net radial increment modelled by applying the Gompertz function (black smooth line). Arrows point to $A_{90 \%}$ (date when $90 \%$ of the annual radial increment is reached). b Mean daily stem temperature (ST). Solid black lines indicate $0{ }^{\circ} \mathrm{C}$, and dotted black lines indicate $5{ }^{\circ} \mathrm{C}$. $\mathbf{c}$ Number of cambial cells and $\mathbf{d}$ enlarging cells which were determined by microcore sampling ( $n=3$ trees per site).
Daily growth rate was calculated on the basis of the modelled radial increment. The dashed vertical grey lines indicate the date after which mean daily ST stays above $5{ }^{\circ} \mathrm{C}$. The solid vertical grey lines indicate the date after which the cambium is noticeably active ( $n$ cambium cells $>n$ dormant cambium cells) and dendrometer records show a continuous increase. At that time, dendrometer records were set to zero. For each respective parameter, scales of the $y$-axis and $x$-axis are identical 


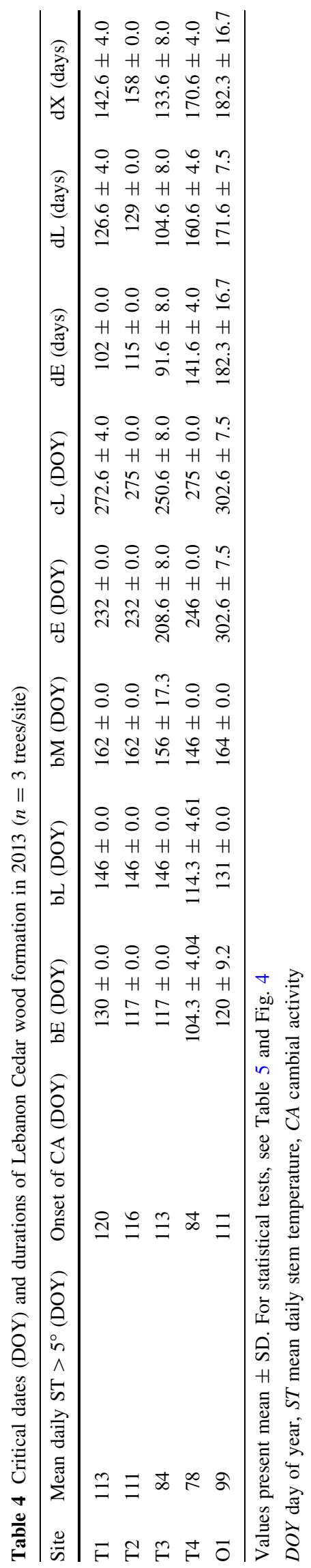

net RSI differed only 1-2 days between all trees at one site but varied clearly between sites. In both years, net RSI was recorded approximately 1-2 weeks after daily mean ST stayed above a threshold of $5^{\circ} \mathrm{C}$ (4 weeks for T3). At this date, dendrometer records were set to zero for growth modeling and dSRV-climate analysis (Fig. 3, shown for 2013). In 2014, after winter dormancy, the critical ST threshold of $5^{\circ} \mathrm{C}$ was reached about 5 days earlier at the Turkish sites and 8 days earlier at the German site as compared to 2013. Radial growth modelled by Gompertz fittings described the course of RSI from dendrometer records very well $\left(R^{2}=0.93-0.99\right.$; Table 6; Fig. 3a). To test for between-site differences of parameters obtained from Gompertz fittings, ANOVA was performed (Table 6). Mean $A$ varied between 0.98 and $4.47 \mathrm{~mm}$ and did significantly differ between sites (ANOVA, $F=21.73$, $p<0.001$ for 2013 and $F=12.53, p<0.001$ for 2014) with the highest $A$ observed at $\mathrm{O} 1$ and the lowest at T2 and T3. Trees at sites with lower LAI tended to have higher $A$ (Fig. 5a). Maximum growth rate at $t_{\mathrm{p}}$ was significantly higher at O1 (ANOVA, $F=26.53, p<0.001$ for 2013 and $F=6.51, p<0.01$ for 2014). Mean $r$ varied between 8.23 and $32.7 \mu \mathrm{m}$ and was also significantly higher at $\mathrm{O} 1$ compared to the Turkish sites in 2013 (ANOVA, $F=23.46, p<0.001)$. Within the Turkish sites, T1 showed highest $r$ in both years (ANOVA, $F=8.05$, $p<0.01$ for 2014). Timings of $t_{\mathrm{p}}$ occurred mainly around the beginning of June (ANOVA, $F=1.58, p>0.05$ for 2013 and $F=25.06, p<0.001$ for 2014).

\section{Inter-annual variability}

To test for significant differences between years, $t$ tests were performed on parameters obtained from Gompertz curve fittings (Table 6). In 2014, $A$ was significantly higher at T1 $(t=-4.6, p<0.01)$ and T4 $(t=-2.3, p<0.05)$, and significantly lower at $\mathrm{O} 1(t=4.6, p<0.05)$ compared to 2013. Changes in $A$ at T2 and T3 were not significant ( $p>0.05$, Fig. 5b). Maximum growth rate at $t_{\mathrm{p}}$ showed significant differences at T4 (higher value in 2014, $t=-7.9, p<0.001$ ) and $\mathrm{O} 1$ (higher value in 2013, $t=6.7, p<0.01)$. Mean $r$ increased significantly in 2014 at T1 $(t=-4.8, p<0.01)$ and T4 $(t=-6.7, p<0.001)$ and decreased significantly at $\mathrm{O} 1(t=6.6, p<0.01)$. At $\mathrm{T} 3$, none of the parameters differed significantly between years.

\section{Relation between wood formation phenology and stem growth dynamics}

For all studied Lebanon Cedar trees, onset of CA, as characterized by a significant increase in the number of cambial cells (Fig. 3c), appeared at the same time when 
Table 5 Statistics for the Kruskal-Wallis test between critical dates (DOY) and durations at the five Lebanon Cedar study sites

\begin{tabular}{lllllcccc}
\hline & $\mathrm{bE}$ & $\mathrm{bL}$ & $\mathrm{bM}$ & $\mathrm{cE}$ & $\mathrm{cL}$ & $\mathrm{dE}$ & $\mathrm{dL}$ & $\mathrm{dX}$ \\
\hline$\chi^{2}$ & 9.95 & 13.90 & 8.63 & 13.84 & 13.03 & 13.77 & 13.17 \\
$p$ & $\mathbf{0 . 0 4 1}$ & $\mathbf{0 . 0 0 8}$ & 0.071 & $\mathbf{0 . 0 0 8}$ & $\mathbf{0 . 0 1 1}$ & $\mathbf{0 . 0 0 8}$ & $\mathbf{0 . 0 1 0}$ & $\mathbf{0 . 0 1 2}$ \\
\hline
\end{tabular}

Significant values at $p<0.05$ are bold
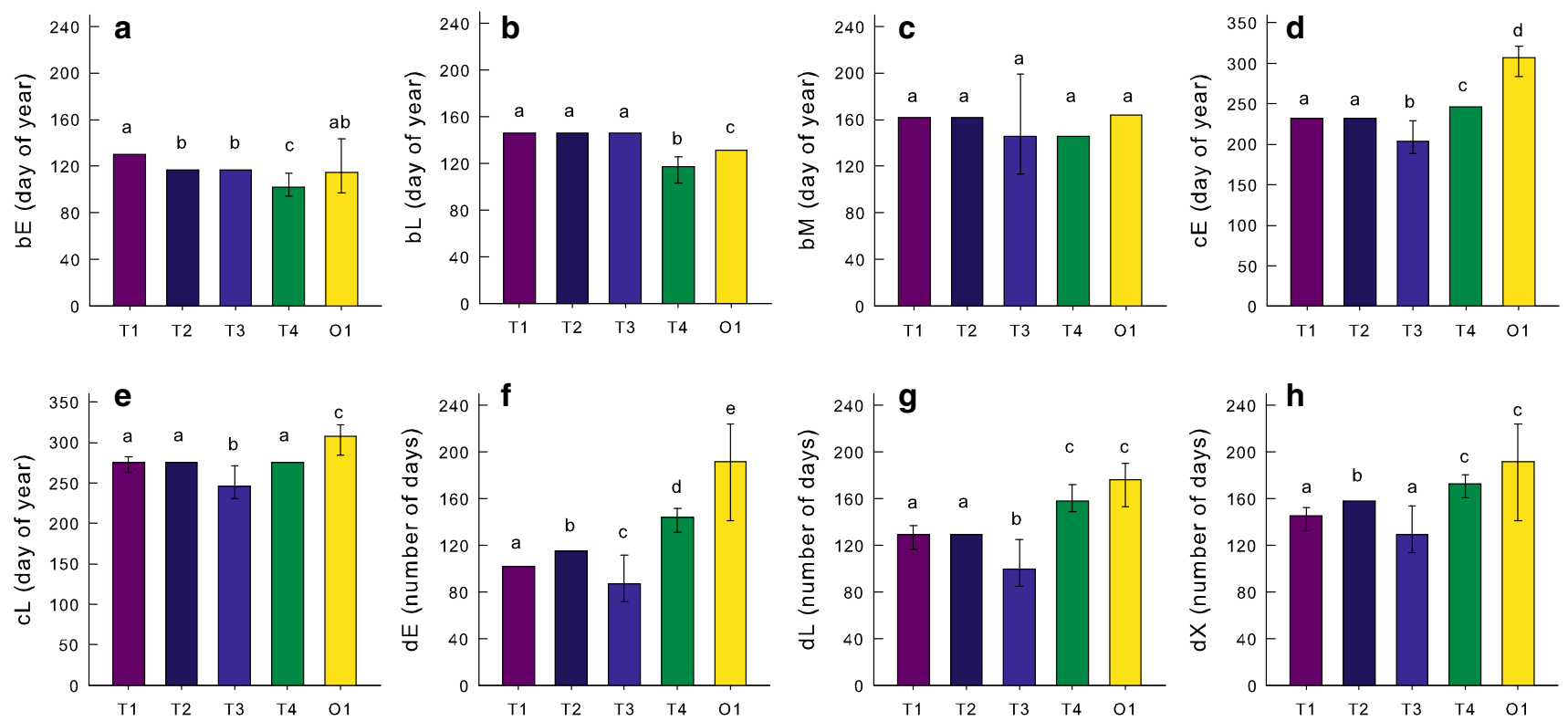

Fig. 4 Comparison of critical dates (DOY) and durations of wood formation computed from raw cell count data of Lebanon Cedar between the study sites (T1 to T4: Turkish sites and O1: German site) in 2013. bE, bL, and bM stand for onset of enlarging, cell-wall lignification, and mature phases, $\mathrm{cE}$ and $\mathrm{cL}$ for cessation of enlarging and cell-wall lignification phases, and $\mathrm{dE}, \mathrm{dL}$, and $\mathrm{dX}$ stand for

dendrometer records indicated a net linear increase in stem radii (Fig. 3a, c). At all sites, $\mathrm{CA}$ and $\mathrm{dE}$ were within the time span of net RSI (Fig. 3). Daily growth rates, calculated as first derivatives on the basis of the modelled radial increment (Gompertz curve fit), followed very well the course of number of enlarging cells obtained from microcores (Fig. 3d). Maximum growth rate occurred around the same time as the maximum number of enlarging cells and before summer solstice (DOY 172).

Gompertz curves fitted very well the measured RSI from both, dendrometer records (Fig. 3a) and microcore samples (not shown). The proportion of variance explained varied between 0.81 and $0.99\left(R^{2}\right.$, Table 6). In 2013, Gompertz fittings on the ring widths from both, microcore samples and dendrometer records, highly significantly correlated with each other $(p<0.05$, Fig. 6). Values for $A$ were always higher for dendrometer records, except for $\mathrm{T} 4$ (Fig. 6a). The larger growth estimates by dendrometers included also phloem cells, while microcores include xylem cells, only. Growth rate $r$ was very similar for T2,

durations of the enlarging and lignification phases as well as the duration of xylogenesis. Bars correspond to the $95 \%$ confidence limits of the median ( $n=3$ trees per site). Different letters indicate significant differences among groups $(p<0.05)$ within a graph based on Mann-Whitney $U$ tests

$\mathrm{T} 3$, and $\mathrm{O} 1$, higher for dendrometer records at $\mathrm{T} 1$ and markedly lower for dendrometer records at T4 (Fig. 6b). Timing of $t_{\mathrm{p}}$ occurred generally later in microcores (Fig. 6c). Apart from two exceptions (one tree at $\mathrm{O} 1$ and T1), $d$ was always higher for dendrometer records (Fig. 6d).

\section{Daily stem radius variation ( $\mathrm{dSRV})$ in relation to meteorological factors}

Among the Turkish sites, dSRV were quite synchronous (Fig. 7a-d). During the main period of net RSI (see Fig. 3), dSRV varied from -0.057 to $+0.128 \mathrm{~mm}$ at the Turkish sites and from -0.052 to $+0.257 \mathrm{~mm}$ at the German site (Fig. 7e). Only few negative dSRV values occurred during this period. At all sites, dSRV responded quite similarly to meteorological factors. Pearson correlation coefficients were calculated for dSRV and ten climate variables (Fig. 8). At all five sites, dSRV showed closest correlations $(p<0.01)$ to $\mathrm{rH}$ and $\mathrm{Pp}$ (both positive correlations). 


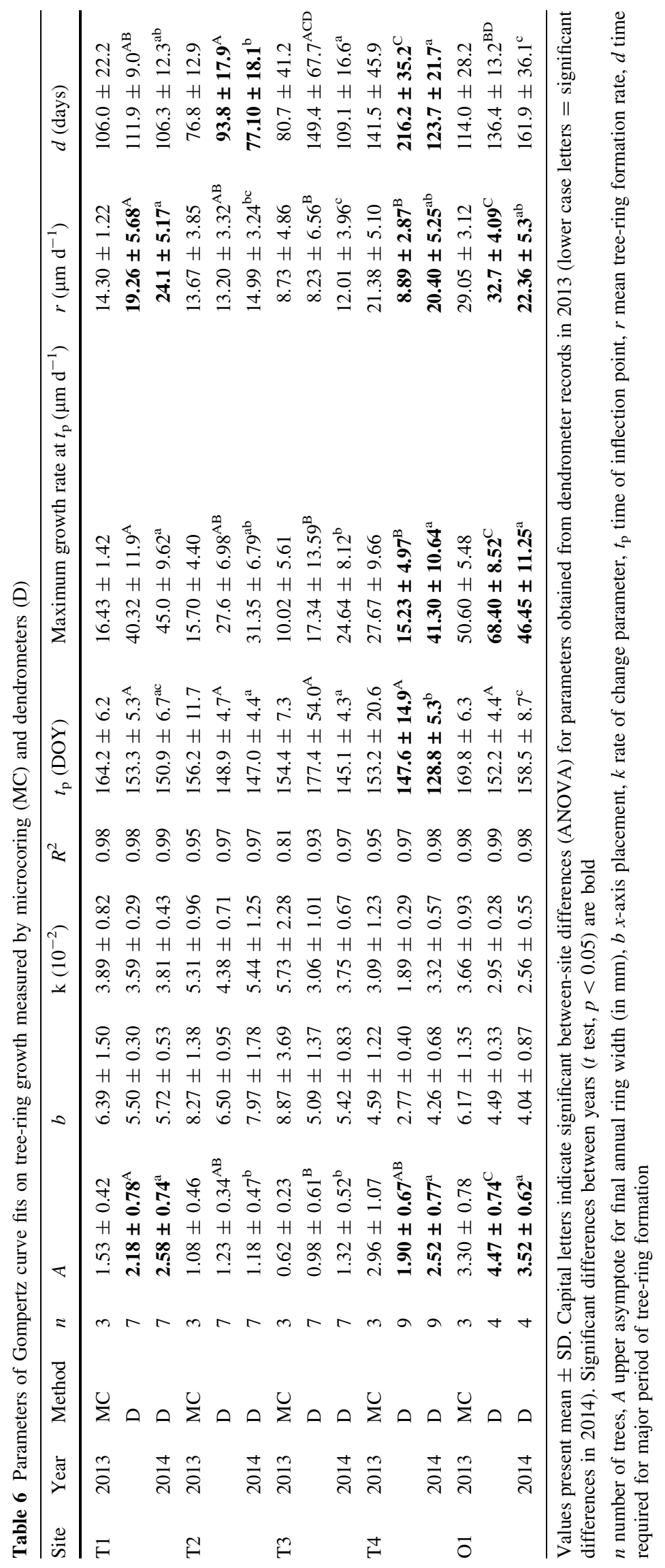



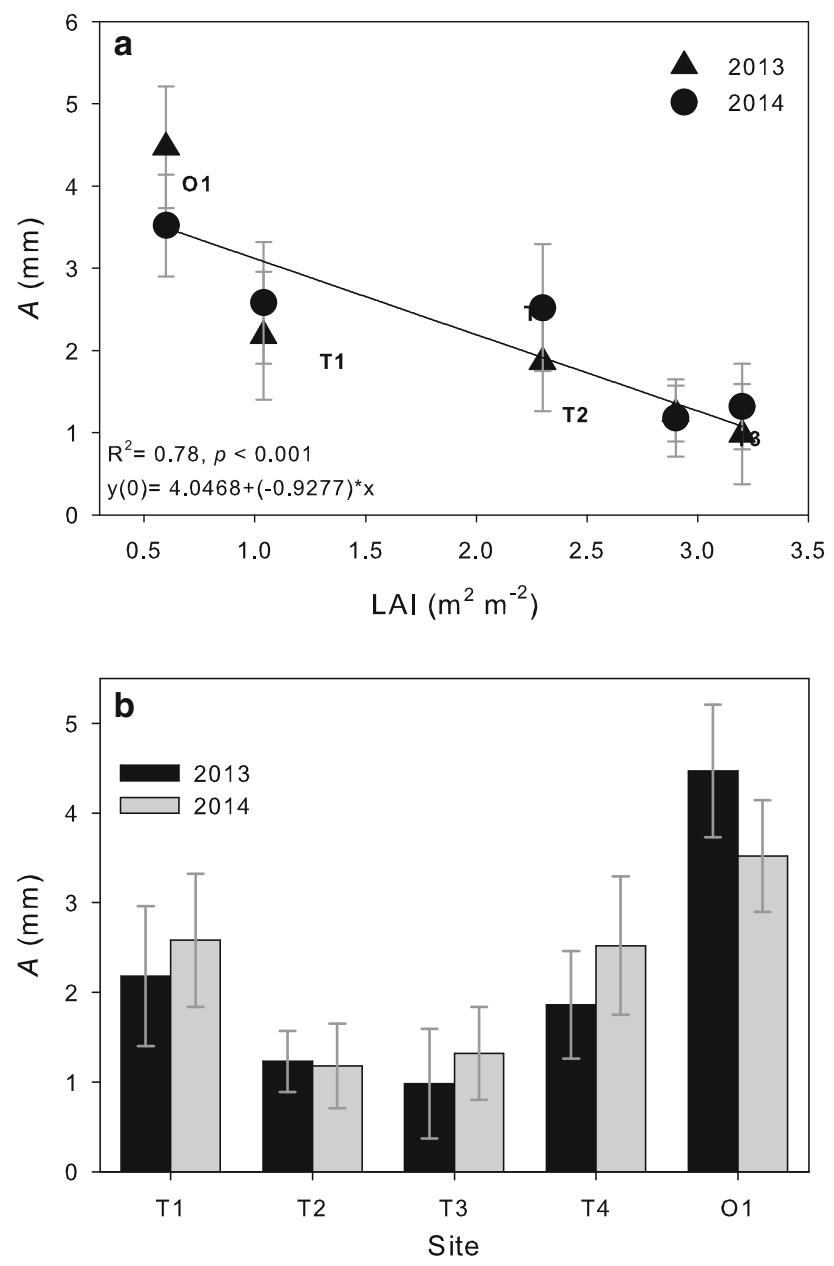

Fig. 5 a Relationship between mean total annual tree-ring widths (A) and LAI and $\mathbf{b} A$ of Lebanon Cedar obtained from dendrometer measurements and Gompertz fittings for the measurement sites (T1 to T3: $n=7$, T4: $n=9$, O1: $n=4$ ) at the end of the growing season in either 2013 (black bars) or 2014 (grey bars). Error bars indicate $\pm \mathrm{SD}$

Significant negative correlations of dSRV $(p<0.01)$ were found for $\mathrm{gR}$ and VPD. Less tight relations were found for $\mathrm{Ta}_{\max }$ (negative correlation). Only at O1, dSRV showed a significant positive correlation to $\mathrm{Ta}_{\min }$ and SWC. $\mathrm{T} 1, \mathrm{~T} 3$, and $\mathrm{T} 4$ showed a significant negative correlation and linear relationship to ST. No correlations were found for dSRV and $\mathrm{Ts}$ at all sites. At all sites, simple linear regressions showed significant correlations between dSRV and $\mathrm{Ta}_{\max }$, Pp, rH, VPD, and gR (Fig. 9) and none between dSRV and SWC. Multiple linear regression models explained between 30 and $51 \%$ of the variation in dSRV during the main period of net RSI (Table 7). Because of different lengths in the growing seasons and for missing data, the number of days analyzed in the regression models varied between sites. Standardized coefficients $(\beta)$ show that $\mathrm{rH}$ had the greatest influence on dSRV at most sites (except T2 and T3) and for "all sites". The model for T2 did not include
rH but instead of that Ts had the highest impact on dSRV. $\mathrm{Pp}$ was present in all models with different degrees of influence. Only at O1, SWC was not included in the model.

\section{Discussion}

\section{Microcore sampling and dendrometer records in studies on wood formation}

In many studies, microcore sampling was successfully used to address interrelationships of growth in various tree species and ecosystems: e.g., with climate (Camarero et al. 2010; Oberhuber and Gruber 2010; Rossi et al. 2008b), with wood formation along altitudinal (Moser et al. 2010) and latitudinal gradients (Huang et al. 2011), in different parts of a tree (Thibeault-Martel et al. 2008) or as related to tree age or social status (Rathgeber et al. 2011a; Rossi et al. 2008a). All these studies contributed to a better understanding of factors controlling wood formation. However, some issues that remain open when using microcore sampling are that it is quite costly and time consuming, which limits sampling intervals. Furthermore, growth heterogeneity in wood formation may result in different wood formation dynamics around the stem. Therefore, attempts of standardizing cell numbers were made (Deslauriers et al. 2008). In our study, we sampled three trees per site at biweekly intervals, which in our analysis caused some critical dates to be seemingly the same (e.g., $\mathrm{cE}$ and $\mathrm{cL}$ at $\mathrm{O} 1$, see Table 4). Still, an altitudinal gradient was visible, with earlier onsets (critical dates) and longer durations at lower sites. In comparison, when using dendrometers to record stem radius changes, the quantification of cambial growth and determination of critical timings of wood formation still remain problematic (Chan et al. 2016; Mäkinen et al. 2008). Therefore, most of the studies using dendrometers investigate stem water status and short-term growth responses to changing environmental conditions by extracting dSRV (Drew and Downes 2009; Wimmer et al. 2002; Zweifel and Häsler 2001). Recent promising studies increasingly focus on how to separate cambial growth and wood formation from other signals that lie within the measured dSRV (Chan et al. 2016; Deslauriers et al. 2003b; Zweifel et al. 2016). A combination of both methods (dendrometers and microcoring) is generally used to set dendrometer records to zero when CA or first enlarging cells are detected based on microcore samples (Oberhuber et al. 2014). Dendrometer records in Lebanon Cedar showed the beginning of a quasi-linear increase in radius at the time when onset of CA was detected by a clear increase of cambial cell number. Studies of Linares et al. (2009) on the Mediterranean conifer Abies pinsapo, showed that, because of the swelling of the stem, growth 
Fig. 6 Relationships between parameters obtained from Gompertz fittings either for microcore samples (MC) or for dendrometer records (D), as measured on Lebanon Cedar. One symbol represents one tree ( $n$ trees per site $=3$, circles $\mathrm{T} 1$, squares $\mathrm{T} 2$, diamonds $\mathrm{T} 3$, crosshairs $\mathrm{T} 4$, and triangles O1). a $A$ total annual tree-ring width, $\mathbf{b} r$ mean growth rate (during the main period of treering formation), $\mathbf{c} t_{\mathrm{p}}$ time of inflection point. $\mathbf{d} d$ main period of tree-ring formation
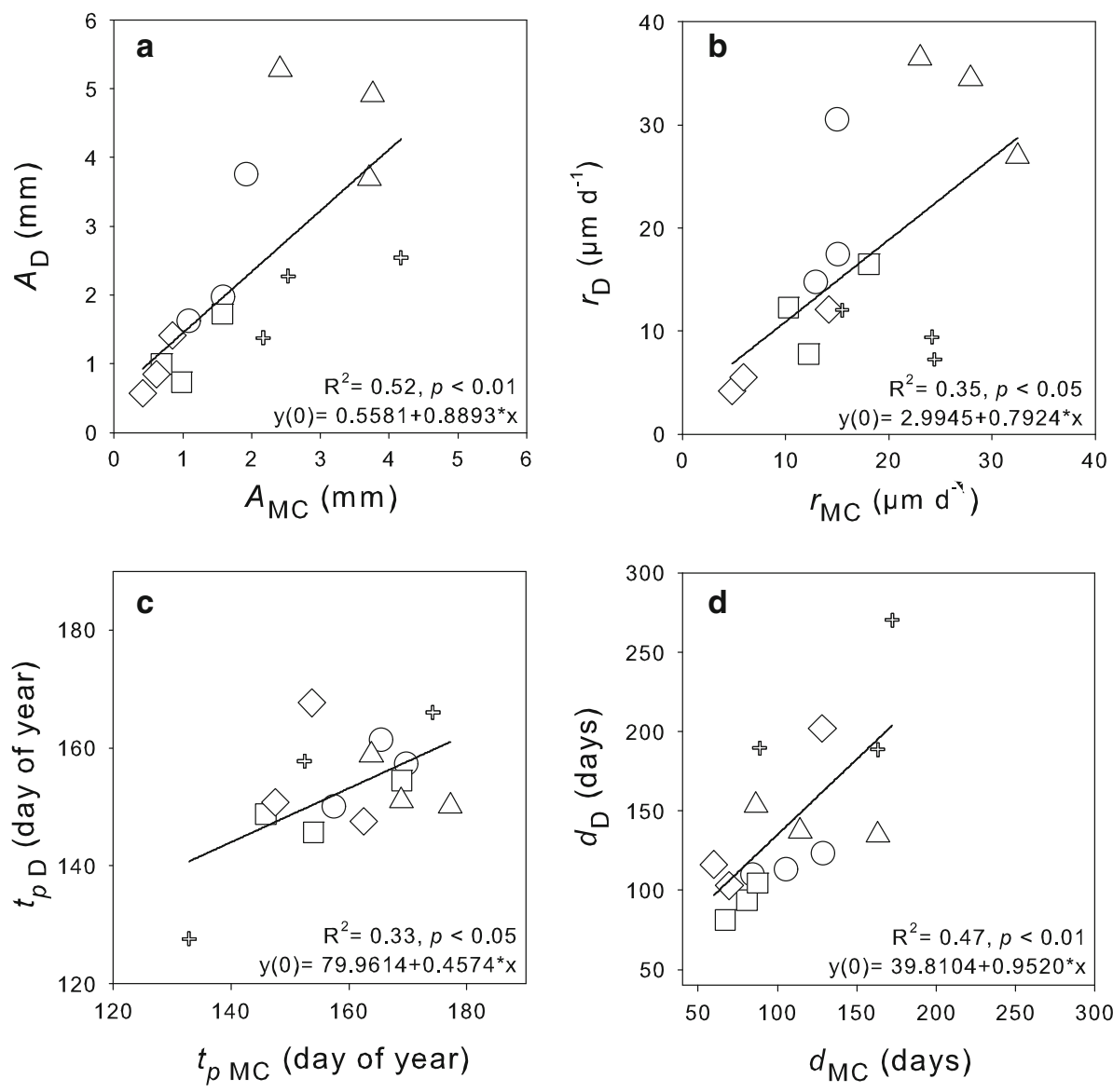

onset seemed to start almost 3 weeks earlier according to dendrometer records than actually measured by microcores. In our study, we could clearly observe the beginning of CA by dendrometers with a difference of only 1-2 days. The phase shift between both methods may be minimized by an almost complete removal of bark and cortex, where the point dendrometers are placed. We, furthermore, have indications (measurement of xylem tension via pressure bomb, data not shown) that at our sites, stems of Lebanon Cedar were already fully rehydrated before onset of CA due to good water supply during early spring (Deslauriers et al. 2003b).

Overall, dendrometer records and microcores provided useful results concerning the radial growth patterns in Lebanon Cedar, and the Gompertz function was suitable for modeling its growth dynamics because of its monotonous growth pattern (Linares et al. 2009). Comparing Gompertz curve fittings on ring width data from microcoring and dendrometer records shows a highly significant correlation (see Fig. 6). Measured $A$ were more likely to be higher in dendrometer records and timings of $t_{\mathrm{p}}$ occurred later in microcores. This seemed apparently to be mainly caused by phloem growth. Growth heterogeneity around the stem could have also lead to differences between dendrometer and microcore results. Our results show the potential that both methods could be linked if approaches may be found that minimize or neutralize effects, such as, e.g., phloem growth. Therefore, further studies which combine both methods are needed to increase the compliance of results obtained from dendrometer records and microcores. In the long term, it may be possible to continuously monitor actual wood formation in high resolution and to differentiate between the different phases of the developing tree ring with the help of dendrometer records.

\section{Growth behavior of Lebanon Cedar at different sites and climates}

Growth behavior of Lebanon Cedar varied with respect to site-climate and other site characteristics but revealed no marked altitudinal gradient. Its annual course of stem growth was typical for trees of the temperate region starting in spring, ending in autumn, and resting during winter (Mäkinen et al. 2003), resulting in the characteristic "sshape" (logistic growth curve), as, e.g., reported by Rossi et al. (2006b). We did not observe any severe stress symptoms at any of the study sites that might have 


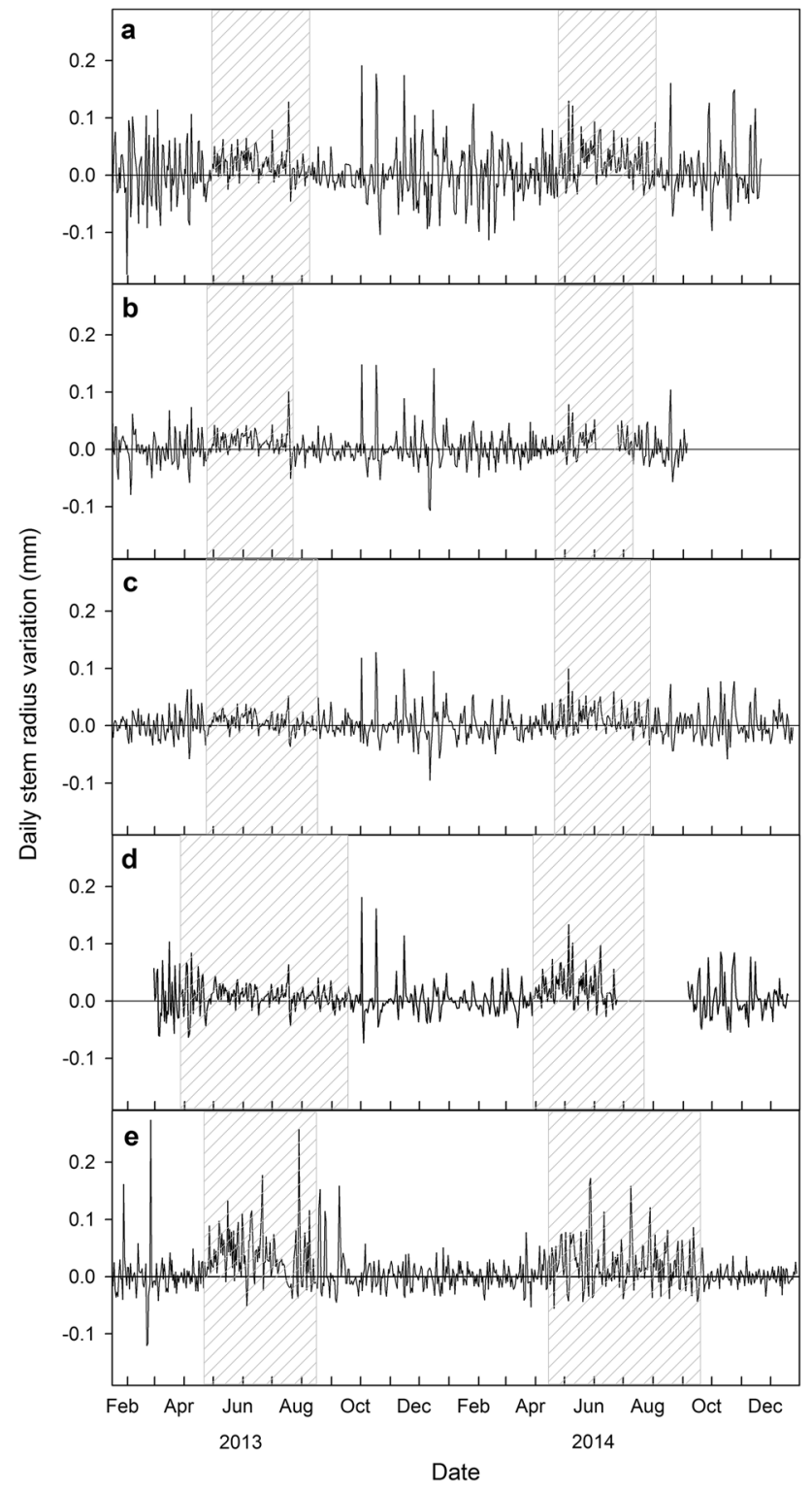

Fig. 7 Annual courses of mean daily stem radius variations (dSRV) in Lebanon Cedar measured in 2013 and 2014 at the Turkish sites a $T 11960 \mathrm{~m}$, b $T 21665 \mathrm{~m}$, c $T 31350 \mathrm{~m}$, d $T 41055 \mathrm{~m}$, and e the German site $O 1360 \mathrm{~m}$. Grey shadings indicate the main periods of net radial stem increases considered for dSRV analysis

markedly early terminated or interrupted growth. A bimodal growth pattern with cambial rest during summer drought, as reported for some conifers from the Mediterranean, was also absent (Camarero et al. 2010; de Luis et al. 2007; Linares et al. 2009; Liphschitz and Lev-Yadun 1986; Vieira et al. 2014).

A clear threshold in temperature and initiation of $\mathrm{CA}$ in spring was reported in several studies on conifers of high altitudes which range from 4 to $5{ }^{\circ} \mathrm{C}$ for daily $\mathrm{Ta}_{\min }$ and 7.2-9.5 ${ }^{\circ} \mathrm{C}$ for mean ST (Anfodillo et al. 2012; Deslauriers et al. 2008; Rossi et al. 2007, 2008b). We observed an ST
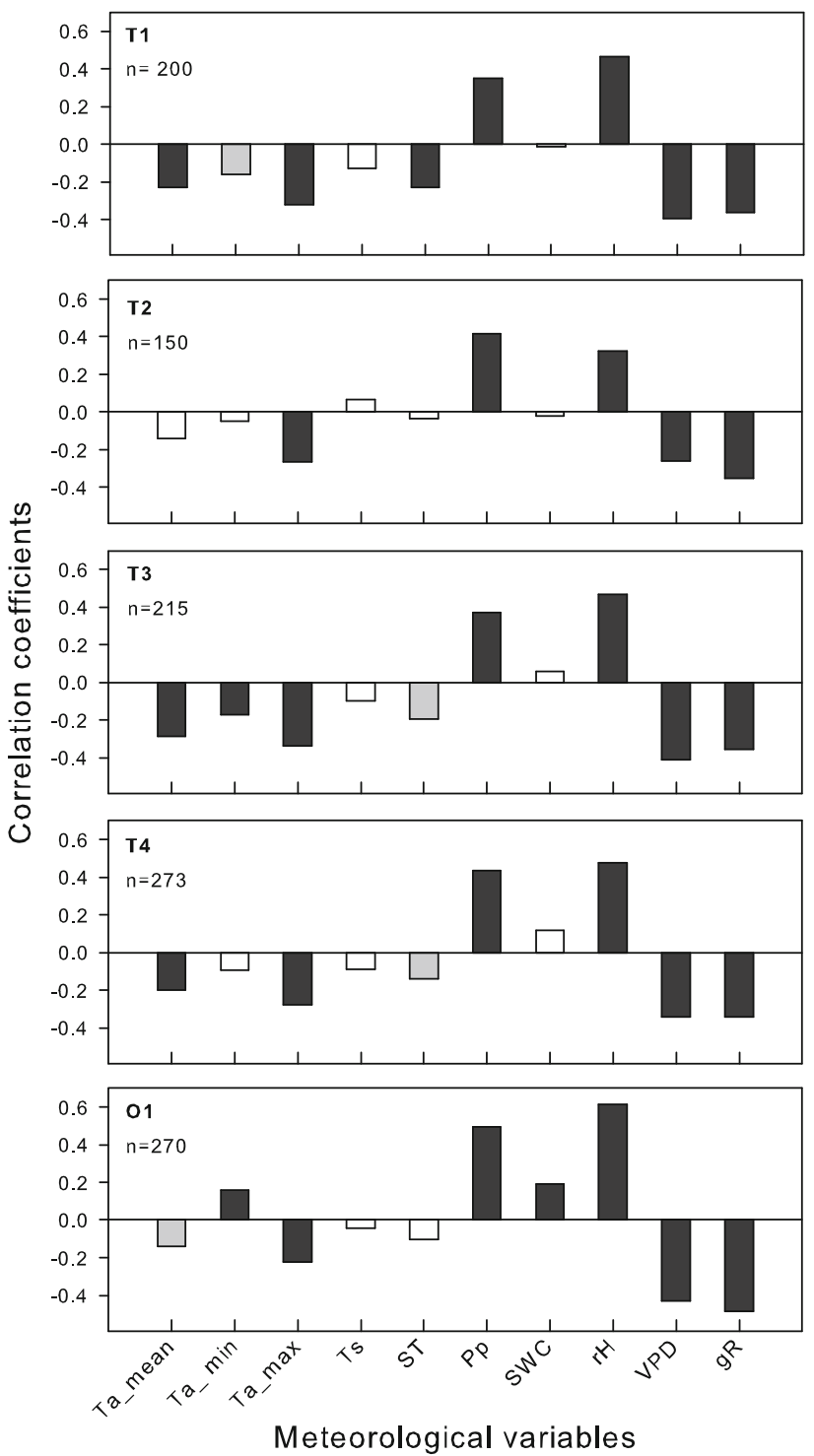

Fig. 8 Pearson correlation coefficients between daily stem radius variation (dSRV) of Lebanon Cedar and meteorological climate variables ( $T a$ air temperature, $T s$ soil temperature, $S T$ stem temperature, $P p$ precipitation, $S W C$ soil water content, $r H$ relative air humidity, $V P D$ vapor pressure deficit, $g R$ global radiation) at the five study sites during the main growth period in 2013 and 2014. Ts, ST, SWC, rH, and VPD represent daily means, and Pp and gR represent daily sums. Level of significance: $p<0.05$ for grey bars; $p<0.001$ for dark grey bars (n.s. = white bars)

threshold of $5{ }^{\circ} \mathrm{C}$ after which the cambium needed 1-2 weeks to become active (except at T3). During this time, air temperatures sometimes dropped below zero for a short while, but living tissues seemed to be sufficiently isolated by the bark. The delay in onset of CA at $\mathrm{T} 3$ could underline the importance of light availability on growth of Lebanon Cedar. T3 had the highest stand density and LAI, and when taking the exposition and slope of this site into account, favorable light conditions at the beginning of the 

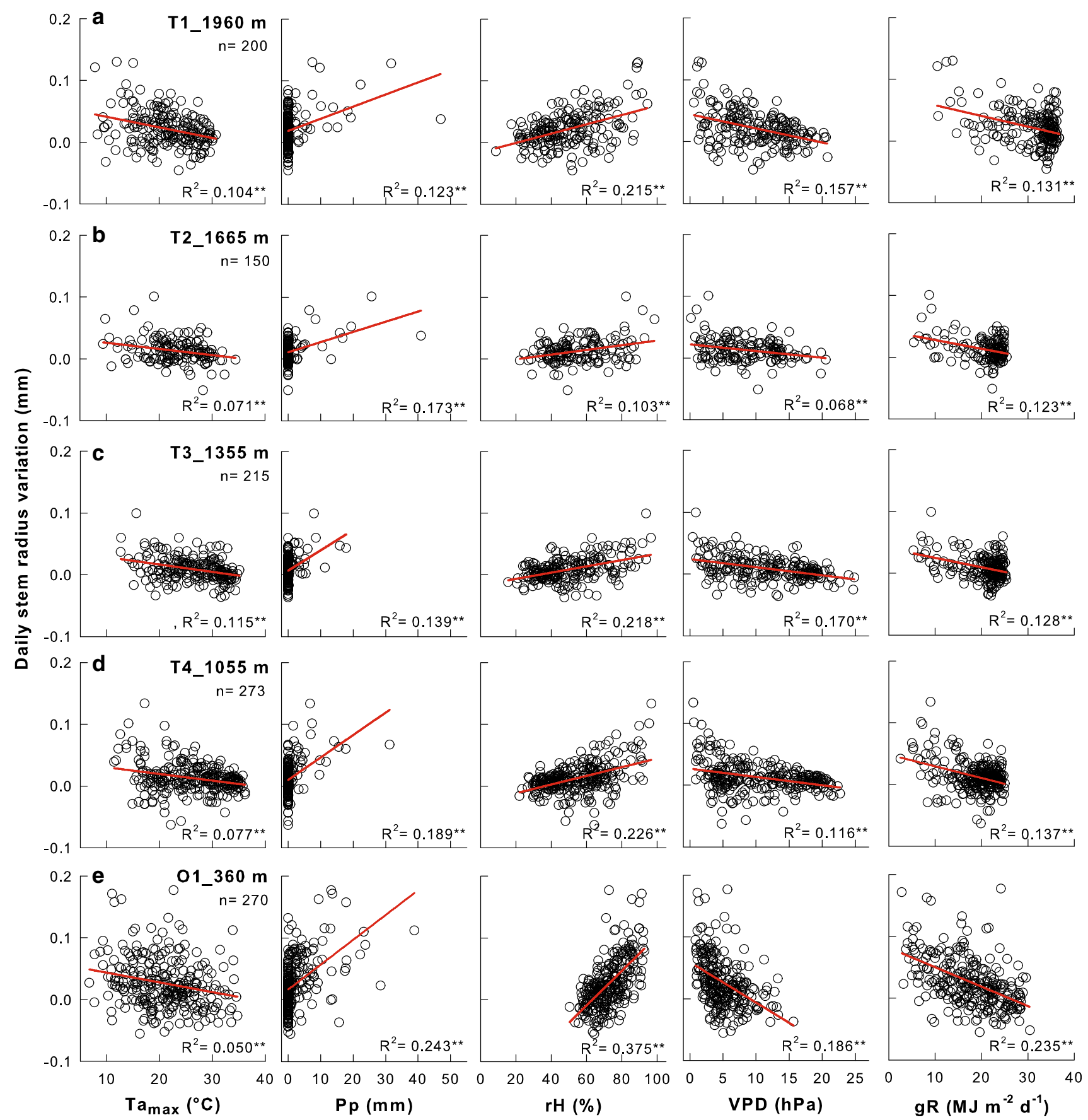

Fig. 9 Relationship between daily stem radius variation (dSRV) of Lebanon Cedar and daily meteorological climate variables during the main growth period in 2013 and $2014\left(T a_{\max }\right.$ maximum air temperature, $P p$ precipitation sum, $r H$ mean relative air humidity,

$V P D$ mean vapor pressure deficit, and $g R$ global radiation sum) at the five study sites (a-d Turkish sites; e German site). For each respective parameter, scales of the $y$-axis and $x$-axis are identical. $n$ number of days per site. Level of significance: $* p<0.05$; ** $p<0.01$

growing season may have occurred later than compared to the other sites. Lebanon Cedar as a light-demanding species (Senitza 1989) might, therefore, had to face a delay of becoming physiologically and photosynthetically active, since assimilated carbon is needed for structural investment into new xylem cells (Rossi et al. 2007). A delayed rise of sap flux density (measured, but not shown) underlines the

suggestion that unfavorable light conditions in early spring could lead to a delay in growth initiation at T3. In fact, light availability influences the overall growth performance: Trees of sites of the highest LAI and stand density (T2 and T3) exhibited the lowest growth rates and formed the thinnest tree rings (dendrochronological analysis performed on 15 trees per site; data not shown). Furthermore, 
Table 7 Results of the multiple linear regression analysis between dSRV (dependent variable) and meteorological variables for Lebanon Cedar during the growth period of 2013 and 2014

\begin{tabular}{|c|c|c|c|c|c|c|c|c|}
\hline Site & $n$ & $R^{2}$ & b0 & Climate parameter & Regression coefficient & $\beta$ & $\mathrm{t}$ & $p$ \\
\hline \multirow[t]{4}{*}{$\mathrm{T} 1$} & 200 & 0.35 & 25.67 & $\mathrm{rH}$ & 0.75 & 0.46 & 6.92 & $<0.001$ \\
\hline & & & & SWC & -1.69 & -0.39 & -5.38 & $<0.001$ \\
\hline & & & & $\mathrm{Pp}$ & 1.68 & 0.30 & 4.76 & $<0.001$ \\
\hline & & & & DOY & -0.16 & -0.17 & -2.40 & $<0.001$ \\
\hline \multirow[t]{4}{*}{$\mathrm{T} 2$} & 150 & 0.37 & -15.01 & Ts & 4.79 & 0.90 & 5.44 & $<0.001$ \\
\hline & & & & $\mathrm{Ta}_{\max }$ & -2.49 & -0.66 & -6.17 & $<0.001$ \\
\hline & & & & $\mathrm{Pp}$ & 1.31 & 0.33 & 4.77 & $<0.001$ \\
\hline & & & & SWC & 0.83 & 0.31 & 2.19 & $<0.05$ \\
\hline \multirow[t]{4}{*}{$\mathrm{T} 3$} & 215 & 0.33 & 40.70 & SWC & -1.08 & -0.58 & -4.82 & $<0.001$ \\
\hline & & & & $\mathrm{rH}$ & 0.53 & 0.49 & 6.81 & $<0.001$ \\
\hline & & & & DOY & -0.24 & -0.41 & -3.48 & $<0.01$ \\
\hline & & & & $\mathrm{Pp}$ & 1.82 & 0.21 & 3.28 & $<0.01$ \\
\hline \multirow[t]{3}{*}{$\mathrm{T} 4$} & 273 & 0.32 & -17.91 & $\mathrm{rH}$ & 0.71 & 0.48 & 7.13 & $<0.001$ \\
\hline & & & & $\mathrm{Pp}$ & 2.20 & 0.26 & 4.71 & $<0.001$ \\
\hline & & & & SWC & -0.59 & -0.21 & -3.36 & $<0.01$ \\
\hline \multirow[t]{4}{*}{$\mathrm{O} 1$} & 270 & 0.52 & -206.11 & $\mathrm{rH}$ & 3.20 & 0.70 & 11.89 & $<0.001$ \\
\hline & & & & $\mathrm{Ta}_{\text {mean }}$ & 3.49 & 0.37 & 6.19 & $<0.001$ \\
\hline & & & & DOY & -0.32 & -0.31 & -6.01 & $<0.001$ \\
\hline & & & & $\mathrm{Pp}$ & 1.73 & 0.21 & 4.34 & $<0.001$ \\
\hline \multirow[t]{3}{*}{ All } & 1108 & 0.30 & -16.31 & $\mathrm{rH}$ & 0.68 & 0.41 & 12.84 & $<0.001$ \\
\hline & & & & $\mathrm{Pp}$ & 2.25 & 0.32 & 11.69 & $<0.001$ \\
\hline & & & & SWC & -0.45 & -0.17 & -5.62 & $<0.001$ \\
\hline
\end{tabular}

Climate parameters are listed according to their weight in the model (from high to low)

The multiple regression analyses followed the general model dSRV $=\mathrm{b} 0+b_{1} \times x_{1}+b_{2} \times x_{2}+\cdots$ $+b_{\mathrm{i}} \times x_{\mathrm{i}}$, where $\mathrm{b} 0$ is the constant and $b_{\mathrm{i}}$ represents the respective regression coefficient

For all Models and parameters, the level of significance $(p)$ is $<0.05$

$n$ number of days analyzed, $R^{2}$ coefficient of determination, $\beta$ standardized coefficient which shows the relative importance of the independent variable, and $t$ value of $t$ statistic light availability appears to play an important role concerning culmination of growth. At all sites, growth culminated before or around summer solstice, which leaves enough time for the trees in the remaining growth season to complete the differentiation of newly formed tracheids before winter (Rossi et al. 2006c, 2008b).

Compared to 2013, in 2014, annual tree rings were significantly wider at the Turkish sites T1 and T4, which could be explained by the fact that in 2014, TAP was higher and summer drought was less severe. Other studies from Mediterranean ecosystems (Camarero et al. 2010; Linares et al. 2009; Vieira et al. 2014) and dendrochronological studies on Lebanon Cedar (Akkemik 2003) showed that low precipitation was an important factor limiting tree growth during summer and Ren et al. (2015) demonstrated how precipitation triggers onset of xylogenesis in Qilian juniper. The earlier onset of growth (the threshold ST of $5{ }^{\circ} \mathrm{C}$ was reached approximately 1 week earlier) allowed for a longer period of xylogenesis and, thus, could have favored the formation of wider tree rings (e.g., Lupi et al. 2010). Furthermore, the favorable growth conditions at the beginning of the growing season seemed to cause higher growth rates which also corresponded with wider tree rings in Lebanon Cedar. This was already stated in other wood formation studies on conifers (Cuny et al. 2012; Rathgeber et al. 2011a). Tree rings at O1 were significantly narrower in 2014, although the threshold ST of $5{ }^{\circ} \mathrm{C}$ was reached earlier in 2014 than in 2013 at $\mathrm{O} 1$ causing a longer period of xylogenesis. We, therefore, suggest that the less favorable growth conditions (TAP was lower and rainfall in June 2014 was markedly low at the EBG) lead to lower growth rates thus causing narrower tree rings. At T2 and T3, tree rings were generally very narrow showing no significant differences between the study years (2013 and 2014) as compared to the other sites. Therefore, we suggest that, besides microclimatic conditions, other factors (soil properties, nutrient availability, etc) may also play an important role; obviously, wood-formation patterns in Lebanon Cedar are quite site specific (del Castillo et al. 2016).

Analysis of microclimatic effect on dSRV leads to a better understanding of how Lebanon Cedar responds to 
short-term changes in climate (Urrutia-Jalabert et al. 2015). During the main growth period, dSRV was positively related to $\mathrm{Pp}$ and $\mathrm{rH}$ and negatively related to $\mathrm{Ta}_{\max }$, VPD, and $\mathrm{gR}$. The positive effect of Pp and humidity on SRV was to be expected and had been reported for several conifer and broadleaved species (Deslauriers et al. 2003b; Köcher et al. 2012), as they directly favor cell enlargement by increasing the water status in the stem (Steppe et al. 2015). In comparison, high $\mathrm{Ta}_{\max }$, VPD, and gR exert negative effects on cell turgor and, therefore, tend to inhibit cell enlargement and growth (Pantin et al. 2012). Multiple linear regression analyses allowed for an insight into combined effects of climate parameters on dSRV and revealed that $\mathrm{rH}, \mathrm{SWC}$, and $\mathrm{Pp}$ dominate dSRV. As to be expected, stem growth in Lebanon Cedar was favored by humid conditions during the main growing season, which is in accordance with results from temperate ecosystems (Köcher et al. 2012; Köstner et al. 1998). Downes et al. (1999) stated that soil water is a major determinant of CA. The absence of SWC in the model of O1 (see Table 7) may be due to the generally much moister climate at the EBG with water supply evenly distributed throughout the year. This is in accordance with findings of Köcher et al. (2012) who predict that the influence of atmospheric water status on daily stem growth patterns in temperate broadleaved species is large in comparison with soil water status when for generally moist conditions, no drought periods come up. The rate of the variation in our models showed that dSRV cannot be explained by climate data alone (Downes et al. 1999), and such unknown effects of parameters other than climate should be investigated in future studies; they may increase the explanatory power of the models.

\section{Forecasts on the use of Lebanon Cedar and response to future climate change}

Results from our Turkish study sites show that this species is well adapted to its current local climate conditions but also shows good growth performance under Central European climate. Lebanon Cedars robustness was demonstrated by reforestation projects performing broadcast seeding in bare karstic lands in the Taurus Mountains (40.457 ha until 2005) (Boydak 2007). Successful afforestation projects in Inner-Anatolian regions (Akgül and Y1lmaz 1986) show that Lebanon Cedar is even capable of growing under continental-like climate conditions exhibiting cold winters and low TAP in combination with elongated drought periods during summer [e.g., in areas around Ankara: MAT of $11.6{ }^{\circ} \mathrm{C}$ and TAP of $344 \mathrm{~mm}$, Turkish State Meteorology Service (2005)]. Planting success amounted to 70-90\% inside and $50-80 \%$ outside of its range, respectively (Boydak 2007). We, therefore, expect that in the close future, Lebanon Cedar will not face severe growth stress at its natural distribution range even under expected climate changes in the Mediterranean becoming drier and hotter (Stocker 2014). The discussion intensifies whether it is a potential forest species to establish plantations and/or to substitute indigenous species, e.g., in Central European regions also facing climate change (Huber and Storz 2014; Messinger et al. 2015). Even though local TAP and MAT at the German study site (EBG, Northern Bavaria) are very similar to the Turkish sites, the fact that annual precipitation is distributed evenly throughout the year seems to be one of the most favorable growth conditions. Growth potential of Lebanon Cedar at the EBG was recently evaluated by Messinger et al. (2015). They showed that the cedar individuals exhibited extraordinary growth with no visible signs of biotic and abiotic damages until now. Furthermore, despite developing wide tree rings, wood properties of felled individuals showed no loss of wood quality (Risse 2013). As a light-demanding species (Senitza 1989), it showed best growth performance in stands of low tree density (Messinger et al. 2015) and low LAI as also observed in our study. Another study in Lebanon Cedar stands near Isparta, SW-Turkey, showed that thinning treatments lead to increases of diameter, basal area, and stem volume (Carus and Catal 2010). Therefore, in plantation projects, it must be ensured that spacing for Lebanon Cedar is sufficient to develop its full growth potential.

\section{Conclusions}

Our study provided insights into intra-annual stem growth of Lebanon Cedar under different site- and climate conditions. High-resolution dendrometer records allowed for assessing climatic sensitivity of dSRV. For precise definitions of critical dates and durations of cambial phenology, microcoring and histological analyses were essential. Further studies on tree-ring formation combining both methods are needed (1) to increase their accuracies and (2) to find traits within dendrometer data which may allow an identification of critical dates and durations consistent to findings from microcoring.

Onset of CA in Lebanon Cedar was observed 1-2 weeks after ST reached a threshold of $5{ }^{\circ} \mathrm{C}$. In this light-demanding species, the delayed start of CA at T3 might be coupled with a relatively high site-LAI. Trees from study sites with lower LAI showed higher growth performances. At short-time scales, primarily moist atmospheric conditions seemed to favor stem growth. Best growth performance was observed for the German site, where water supply was evenly distributed throughout the year.

Lebanon Cedar is tolerant to extremely low winter temperatures and high summer temperatures accompanied 
by drought periods (see Turkish sites), but shows extraordinary growth under more humid climate with continuous water supply (see German site). Therefore, it appears to be a promising forest species to adapt well to future climate scenarios in the Central European region and should be considered for further studies focusing on growth performance under different site and climate conditions.

Author contribution statement AG and RZ generated the study design. AG, RZ, and MŞ performed the field work. AG, MK, and CR analyzed data. AG wrote the manuscript with contributions from MK and CR. All authors have revised and approved the final manuscript.

Acknowledgements This research was carried out within the project funded by the German Federal Ministry of Education and Research (01DL12041) and in cooperation with the Southwest Anatolian Forest Research Institute (SAFRI) in Antalya and the Ecological Botanical Gardens in Bayreuth (EBG). We would like to thank all who have contributed to this work, with special thanks to Neşat Erkan and the employees of SAFRI as well as to Gregor Aas and the employees at the EBG. Furthermore, we would like to thank Özdemir Şentürk, Serkan Gülsoy, Dieter Schmitt, Helmut Dalitz, Sabine Remmele, and Viviana Horna for their contributions and support.

\section{Compliance with ethical standards}

Conflict of interest The authors declare that they have no conflict of interest.

\section{References}

Akgül E, Yılmaz A (1986) Relationship between growth characteristics of Taurus cedar (Cedrus libani A. Rich) and the ecological properties of reforestation areas outside the natural stands. Ormancılık Araştırma Enstitüsü Müdürlüğü Teknik Bülten Serisi No 188

Akkemik Ü (2003) Tree rings of Cedrus libani at the northern boundary of its natural distribution. IAWA J 24:63-73

Anfodillo T, Deslauriers A, Menardi R, Tedoldi L, Petit G, Rossi S (2012) Widening of xylem conduits in a conifer tree depends on the longer time of cell expansion downwards along the stem. J Exp Bot 63:837-845. doi:10.1093/jxb/err309

Basaran MA et al (2008) Determining the actual state of Elmali cedar research forest by GIS based digitl maps (in Turkish with english abstract). Çevre ve Orman Bakanlığ 1 Yayın 353:1-331

Bouriaud O, Leban J-M, Bert D, Deleuze C (2005) Intra-annual variations in climate influence growth and wood density of Norway spruce. Tree Physiol 25:651-660

Boydak M (2007) Reforestation of Lebanon cedar (Cedrus libani A. Rich.) in bare karstic lands by broadcast seeding in Turkey. In: Leone V. (ed.), Lovreglio R. (ed.). Proceedings of the international workshop MEDPINE 3: conservation, regeneration and restoration of Mediterranean pines and their ecosystems. Bari: CIHEAM, 2007. pp 33-42 (Options Méditerranéennes: Série A. Séminaires Méditerranéens; n. 75)

Brooks JR, Jiang L, Ozçelik R (2008) Compatible stem volume and taper equations for Brutian pine, Cedar of Lebanon, and Cilicica fir in Turkey. For Ecol Manage 256:147-151

Camarero JJ, Guerrero-Campo J, Gutiérrez E (1998) Tree-ring growth and structure of Pinus uncinata and Pinus sylvestris in the Central Spanish Pyrenees. Arct Alp Res 30:1-10
Camarero JJ, Olano JM, Parras A (2010) Plastic bimodal xylogenesis in conifers from continental Mediterranean climates. New Phytol 185:471-480. doi:10.1111/j.1469-8137.2009.03073.x

Carus S, Catal Y (2010) Growth response of Lebanon cedar (Cedrus libani) plantations to thinning intensity in Western Turkey. J Environ Biol 31:609-614

Chan T, Hölttä T, Berninger F, Mäkinen H, Nöjd P, Mencuccini M, Nikinmaa E (2016) Separating water-potential induced swelling and shrinking from measured radial stem variations reveals a cambial growth and osmotic concentration signal. Plant, Cell Environ 39:233-244

Cheng C, Gordon IL (2000) The Richards function and quantitative analysis of germination and dormancy in meadowfoam ( $\mathrm{Lim}$ nanthes alba). Seed Sci Res 10:265-277

Ciais P et al (2005) Europe-wide reduction in primary productivity caused by the heat and drought in 2003. Nature 437:529-533

Cocozza C, Palombo C, Tognetti R, La Porta N, Anichini M, Giovannelli A, Emiliani G (2016) Monitoring intra-annual dynamics of wood formation with microcores and dendrometers in Picea abies at two different altitudes. Tree Physiol 00:1-15

Cuny HE, Rathgeber CB, Lebourgeois F, Fortin M, Fournier M (2012) Life strategies in intra-annual dynamics of wood formation: example of three conifer species in a temperate forest in north-east France. Tree Physiol 32:612-625

Cuny HE, Rathgeber CB, Frank D, Fonti P, Fournier M (2014) Kinetics of tracheid development explain conifer tree-ring structure. New Phytol 203:1231-1241

de Luis M, Gričar J, Čufar K, Raventós J (2007) Seasonal dynamics of wood formation in Pinus halepensis from dry and semi-arid ecosystems in Spain. IAWA J 28:389-404

de Luis M, Novak K, Raventós J, Gričar J, Prislan P, Čufar K (2011) Cambial activity, wood formation and sapling survival of Pinus halepensis exposed to different irrigation regimes. For Ecol Manage 262:1630-1638

del Castillo EM, Longares LA, Gričar J, Prislan P, Gil-Pelegrín E, Čufar K, De Luis M (2016) Living on the edge: contrasted woodformation dynamics in Fagus sylvatica and Pinus sylvestris under Mediterranean conditions. Front Plant Sci 7:1-10

Deslauriers A, Morin H, Begin Y (2003a) Cellular phenology of annual ring formation of Abies balsameain the Quebec boreal forest (Canada). Can J For Res 33:190-200. doi:10.1139/x02178

Deslauriers A, Morin H, Urbinati C, Carrer M (2003b) Daily weather response of balsam fir (Abies balsamea (L.) Mill.) stem radius increment from dendrometer analysis in the boreal forests of Quebec (Canada). Trees 17:477-484. doi:10.1007/s00468-0030260-4

Deslauriers A, Rossi S, Anfodillo T (2007) Dendrometer and intraannual tree growth: what kind of information can be inferred? Dendrochronologia 25:113-124. doi:10.1016/j.dendro.2007.05. 003

Deslauriers A, Rossi S, Anfodillo T, Saracino A (2008) Cambial phenology, wood formation and temperature thresholds in two contrasting years at high altitude in southern Italy. Tree Physiol $28: 863-871$

Downes G, Beadle C, Worledge D (1999) Daily stem growth patterns in irrigated Eucalyptus globulus and E. nitens in relation to climate. Trees 14:102-111

Drew DM, Downes GM (2009) The use of precision dendrometers in research on daily stem size and wood property variation: a review. Dendrochronologia 27:159-172. doi:10.1016/j.dendro. 2009.06.008

Ducci F, Fusaro E, Lucci S, Ricciotti L (2007) Strategies for finalizing Conifers experimental tests to the production of improved reproductive materials. In: Proceedings of the Inter. Workshop MEDPINE3 "Conservation, Regeneration and restauration of 
Mediterranean Pines and thei Ecosystems" (Valenzano-BA, 2005) Options médit., Serie A, 2007, vol 75, pp 99-104

Foken T (2007) Das Klima von Bayreuth. Standort 31:150-152. doi:10.1007/s00548-007-0045-X

Gricar J, Zupancic M, Cufar K, Koch G, Schmitt U, Oven P (2006) Effect of local heating and cooling on cambial activity and cell differentiation in the stem of Norway spruce (Picea abies). Ann Bot 97:943-951. doi:10.1093/aob/mcl050

Güney A, Kerr D, Sökücü A, Zimmermann R, Küppers M (2015) Cambial activity and xylogenesis in stems of Cedrus libani A. Rich at different altitudes. Bot Stud. doi:10.1186/s40529-015$0100-\mathrm{z}$

Herzog KM, Häsler R, Thum R (1995) Diurnal changes in the radius of a subalpine Norway spruce stem: their relation to the sap flow and their use to estimate transpiration. Trees 10:94-101

Huang JG, Bergeron Y, Zhai L, Denneler B (2011) Variation in intraannual radial growth (xylem formation) of Picea mariana (Pinaceae) along a latitudinal gradient in western Quebec, Canada. Am J Bot 98:792-800. doi:10.3732/ajb.1000074

Huber G, Storz C (2014) Zedern und Riesenlebensbaum-Welche Herkünfte sind bei uns geeignet? LWF-Wissen 74:63-71

Kavgacı A, Başaran S, Başaran M (2010) Cedar forest communities in Western Antalya (Taurus Mountains, Turkey). Plant Biosystems 144:271-287

Köcher P, Horna V, Leuschner C (2012) Environmental control of daily stem growth patterns in five temperate broad-leaved tree species. Tree Physiol 32:1021-1032

Köstner B, Falge EM, Alsheimer M, Geyer R, Tenhunen JD (1998) Estimating tree canopy water use via xylem sapflow in an old Norway spruce forest and a comparison with simulation-based canopy transpiration estimates. In: Annales des Sciences Forestières, 1998, vol 1-2. EDP Sciences, pp 125-139

Linares JC, Camarero JJ, Carreira JA (2009) Plastic responses of Abies pinsapo xylogenesis to drought and competition. Tree Physiol 29:1525-1536

Liphschitz N, Lev-Yadun S (1986) Cambial activity of evergreen and seasonal dimorphics around the Mediterranean. IAWA J 7:145-153

Lupi C, Morin H, Deslauriers A, Rossi S (2010) Xylem phenology and wood production: resolving the chicken-or-egg dilemma. Plant, Cell Environ 33:1721-1730. doi:10.1111/j.1365-3040. 2010.02176.x

Mäkinen H, Nöjd P, Saranpää P (2003) Seasonal changes in stem radius and production of new tracheids in Norway spruce. Tree Physiol 23:959-968

Mäkinen H, Seo J-W, Nöjd P, Schmitt U, Jalkanen R (2008) Seasonal dynamics of wood formation: a comparison between pinning, microcoring and dendrometer measurements. Eur J Forest Res 127:235-245. doi:10.1007/s10342-007-0199-x

Messinger J, Güney A, Zimmermann R, Ganser B, Bachmann M, Remmele S, Aas G (2015) Cedrus libani: a promising tree species for Central European forestry facing climate change? Eur J Forest Res 134(6):1005-1017

Michelot A, Simard S, Rathgeber C, Dufrene E, Damesin C (2012) Comparing the intra-annual wood formation of three European species (Fagus sylvatica, Quercus petraea and Pinus sylvestris) as related to leaf phenology and non-structural carbohydrate dynamics. Tree Physiol 32:1033-1045

Moser L, Fonti P, Buntgen U, Esper J, Luterbacher J, Franzen J, Frank D (2010) Timing and duration of European larch growing season along altitudinal gradients in the Swiss Alps. Tree Physiol 30:225-233. doi:10.1093/treephys/tpp108

Oberhuber W, Gruber A (2010) Climatic influences on intra-annual stem radial increment of Pinus sylvestris (L.) exposed to drought. Trees 24:887-898
Oberhuber W, Gruber A, Kofler W, Swidrak I (2014) Radial stem growth in response to microclimate and soil moisture in a drought-prone mixed coniferous forest at an inner Alpine site. Eur J Forest Res 133:467-479

Pantin F, Simonneau T, Muller B (2012) Coming of leaf age: control of growth by hydraulics and metabolics during leaf ontogeny. New Phytol 196:349-366. doi:10.1111/j.1469-8137.2012.04273.

Rathgeber CB, Rossi S, Bontemps JD (2011a) Cambial activity related to tree size in a mature silver-fir plantation. Ann Bot 108:429-438. doi:10.1093/aob/mcr168

Rathgeber CBK, Longuetaud F, Mothe F, Cuny H, Le Moguédec G (2011b) Phenology of wood formation: data processing, analysis and visualisation using R (package CAVIAR). Dendrochronologia 29:139-149. doi:10.1016/j.dendro.2011.01.004

Ren P, Rossi S, Gricar J, Liang E, Cufar K (2015) Is precipitation a trigger for the onset of xylogenesis in Juniperus przewalskii on the north-eastern Tibetan Plateau? Ann Bot 115:629-639

Risse M (2013) Holzeigenschaften der Libanonzeder (Cedrus libani A. Rich) aus dem Ökologisch-Botanischen Garten Bayreuth, Master thesis, Technical University of Munich, Faculty of Forest Science and Resource Management, Munich

Rossi S, Anfodillo T, Menardi R (2006a) Trephor: a new tool for sampling microcores from tree stems. IAWA J 27:89-97

Rossi S, Deslauriers A, Anfodillo T (2006b) Assessment of cambial activity and xylogenesis by microsampling tree species: an example at the Alpine timberline. IAWA J 27:383-394

Rossi S, Deslauriers A, Anfodillo T, Morin H, Saracino A, Motta R, Borghetti M (2006c) Conifers in cold environments synchronize maximum growth rate of tree-ring formation with day length. New Phytol 170:301-310. doi:10.1111/j.1469-8137.2006.01660. $\mathrm{x}$

Rossi S, Deslauriers A, Anfodillo T, Carraro V (2007) Evidence of threshold temperatures for xylogenesis in conifers at high altitudes. Oecologia 152:1-12. doi:10.1007/s00442-006-0625-7

Rossi S, Deslauriers A, Anfodillo T, Carrer M (2008a) Age-dependent xylogenesis in timberline conifers. New Phytol 177:199-208. doi:10.1111/j.1469-8137.2007.02235.x

Rossi S et al (2008b) Critical temperatures for xylogenesis in conifers of cold climates. Glob Ecol Biogeogr 17:696-707. doi:10.1111/j. 1466-8238.2008.00417.x

Senitza E (1989) Waldbauliche Grundlagen der Libanonzeder (Cedrus libani A.Rich) im Westtaurus/Türkei. Dissertation der Universität für Bodenkultur in Wien 34, Wien

Steppe K, Sterck F, Deslauriers A (2015) Diel growth dynamics in tree stems: linking anatomy and ecophysiology. Trends Plant Sci 20:335-343

Stocker TF (2014) Climate change 2013: the physical science basis: Working Group I contribution to the Fifth assessment report of the Intergovernmental Panel on Climate Change. Cambridge University Press, Cambridge

Tardif J, Flannigan M, Bergeron Y (2001) An analysis of the daily radial activity of 7 boreal tree species, northwestern Quebec. Environ Monit Assess 67:141-160

Thibeault-Martel M, Krause C, Morin H, Rossi S (2008) Cambial activity and intra-annual xylem formation in roots and stems of Abies balsamea and Picea mariana. Ann Bot 102:667-674. doi:10.1093/aob/mcn146

Turkish State Meteorology Service (2005) Ortalama ve Ekstrem Kıymetler. Meteoroloji Bültenleri, Turkish State Meteorology Service, Ankara

Urrutia-Jalabert R, Rossi S, Deslauriers A, Malhi Y, Lara A (2015) Environmental correlates of stem radius change in the endangered Fitzroya cupressoides forests of southern Chile. Agric For Meteorol 200:209-221 
Vieira J, Rossi S, Campelo F, Freitas H, Nabais C (2013) Seasonal and daily cycles of stem radial variation of Pinus pinaster in a drought-prone environment. Agric For Meteorol 180:173-181

Vieira J, Rossi S, Campelo F, Freitas H, Nabais C (2014) Xylogenesis of Pinus pinaster under a Mediterranean climate. Ann For Sci 71:71-80. doi:10.1007/s13595-013-0341-5

Wang Z, Yang B, Deslauriers A, Bräuning A (2015) Intra-annual stem radial increment response of Qilian juniper to temperature and precipitation along an altitudinal gradient in northwestern China. Trees 29:25-34

Wimmer R, Downes GM, Evans R (2002) High-resolution analysis of radial growth and wood density in Eucalyptus nitens, grown under different irrigation regimes. Ann For Sci 59:519-524
Zhai L, Bergeron Y, Huang JG, Berninger F (2012) Variation in intraannual wood formation, and foliage and shoot development of three major Canadian boreal tree species. Am J Bot 99:827-837. doi:10.3732/ajb.1100235

Zweifel R, Häsler R (2001) Link between diurnal stem radius changes and tree water relations. Tree Physiol 21:869-877

Zweifel R, Zimmermann L, Zeugin F, Newbery DM (2006) Intraannual radial growth and water relations of trees: implications towards a growth mechanism. J Exp Bot 57:1445-1459. doi:10. 1093/jxb/erj125

Zweifel R, Haeni M, Buchmann N, Eugster W (2016) Are trees able to grow in periods of stem shrinkage? New Phytol. doi:10.1111/ nph.13995 